\title{
Expansions and Contractions of Major US Shopping Centers
}

John M. Clapp

Katsiaryna Salavei Bardos

Tingyu Zhou

Follow this and additional works at: https://digitalcommons.fairfield.edu/business-facultypubs Copyright 2012 Springer Science+Business Media, LLC

The post-print version has been archived here with permission from the copyright holder.

\section{Peer Reviewed}

\section{Published Citation}

Clapp, John M., Katsiaryna Salavei Bardos, and Tingyu Zhou. "Expansions and contractions of major US shopping centers." The Journal of Real Estate Finance and Economics 48, no. 1 (2014): 16-56. https://doi.org/10.1007/ s11146-012-9382-z

This item has been accepted for inclusion in DigitalCommons@Fairfield by an authorized administrator of DigitalCommons@Fairfield. It is brought to you by DigitalCommons@Fairfield with permission from the rightsholder(s) and is protected by copyright and/or related rights. You are free to use this item in any way that is permitted by the copyright and related rights legislation that applies to your use. For other uses, you need to obtain permission from the rights-holder(s) directly, unless additional rights are indicated by a Creative Commons license in the record and/or on the work itself. For more information, please contact digitalcommons@fairfield.edu. 


\title{
Expansions and Contractions of Major US Shopping Centers
}

\author{
John M. Clapp \\ University of Connecticut \\ School of Business Administration \\ 2100 Hillside Road Unit 1041 \\ Storrs, CT 06269-1041 \\ Email: johnc@business.uconn.edu \\ Phone: (860) 486-3227 \\ Katsiaryna Salavei Bardos \\ Fairfield University \\ Dolan School of Business \\ 1073 North Benson Road, \\ Fairfield, CT 06824 \\ Email: ksalavei@fairfield.edu \\ Phone: (203)-254-4000, ext 2829 \\ Tingyu Zhou \\ University of Connecticut \\ School of Business Administration \\ 2100 Hillside Road Unit 1041 \\ Storrs, CT 06269-1041 \\ Email: tzhou2@business.uconn.edu \\ Phone: (860) 486-3227
}

April 27, 2011

\section{Submission Version}




\title{
Expansions and Contractions of Major US Shopping Centers
}

\begin{abstract}
We analyze the determinants of expansions and contractions of shopping centers using a unique dataset of property level data for shopping centers in eleven metropolitan areas over the period from 1995 through 2005. We find that shopping centers with large operating costs are less likely to expand and are more likely to contract. Higher expected revenue increases the likelihood of expansion and decreases the likelihood of contraction. For small shopping centers the decision to change gross leasable area (GLA) is largely driven by potential revenue, while the decision to change the number of stores is largely a function of cost. We find weak support for Grenadier's theory that a larger number of competitors reduces the value of option to wait and increases the likelihood of both expansion and contraction. The market share of competitors reduces the likelihood of increasing the number of stores as suggested by the theory of strategic positioning.

Our hypotheses best explain contraction decisions of large shopping centers and expansion decisions of small shopping centers, suggesting that large shopping centers appear to be above equilibrium size and small shopping centers are smaller than equilibrium. We find that both expansions and contractions of GLA are less likely for large shopping centers in MSAs with greater uncertainty about real estate prices, suggesting that the option to delay has value. Moreover, small centers are significantly less sensitive to cost and revenue; since small centers are likely to have greater idiosyncratic risk than large, this provides indirect evidence for a significant delay option.
\end{abstract}




\section{Introduction}

Shopping centers play a vital role in the U.S. economy. Seventy percent of U.S.'s GDP is attributed to consumer spending and forty percent of consumer spending is conducted at shopping centers. ${ }^{1}$ One of the most important economic decisions made by a developer of a shopping center is the costly decision to expand or to contact the scale of operations. However, academic literature that examined redevelopment of shopping centers is very limited. To the best of our knowledge, only one study (Peng and Thibodeau (2011)) examines property level redevelopment decision for commercial real estate; it finds that their model is not significant for retail properties. ${ }^{2}$ We contribute to the literature by analyzing the determinants of expansions and contractions of shopping centers using a unique dataset of property level data for shopping centers in eleven metropolitan areas over the period from 1995 through 2005.

Our study of the contraction decision is particularly timely: even before the global financial crisis (GFC) investment professionals noted a trend away from regional and super-regional centers with full line department stores and towards smaller "life style" centers emphasizing a small town or village shopping experience. In some cases this involved converting enclosed malls with high Heating, Ventilating, and Air Conditioning (HVAC) costs to open air centers. In other cases regional centers have been replaced by "power centers" characterized by big box retailers. ${ }^{3}$ This is sometimes referred to as "demalling." Our study is further motivated by the GFC. Higher unemployment and reduced retail spending has caused discussion of too much retail space per customer. One way to deal with the high operating costs generated by excess retail space is to reduce the size of the centers.

We examine two types of decisions: substantial change in the number of stores

\footnotetext{
1 The $40 \%$ estimate is based on Bureau of Labor Statistics numbers analyzed by Fanning (2005).

${ }^{2}$ Other empirical studies examine new construction rather than capital expenditures for existing properties. See Peng and Thibodeau (2011) for detailed review of this stream of literature.

3 Morris Newman (1999), writing for The Los Angeles Times says “As shoppers find other ways to buy merchandise, several traditional shopping centers--including that famous playground for Valley girls, the former Sherman Oaks Galleria--are being converted to such new hybrids as entertainment centers, "big box" retail centers, office buildings, schools and even housing."
} 
and in Gross Leasable Area (GLA hereafter). Since the change in GLA involves greater degree of irreversibility, this analysis provides one method of controlling for the cost of changing the center. ${ }^{4}$ We separately analyze large and small shopping centers since it is likely that large shopping centers are above equilibrium size and small shopping centers are below equilibrium size. Moreover, large shopping centers provide greater agglomeration economy for consumers. Furthermore, shopping centers might build excess capacity to signal the ability to attract customers and the willingness to compete for market share and thus deter the entry of competitors. Therefore, determinants of expansion and contraction decisions might differ for small and large shopping centers.

Large shopping centers in our sample have higher operating costs and higher expected revenue than small shopping centers. Large shopping centers have more stores (113 versus 33), however store size of larger shopping centers is less than half of that of small shopping centers. Although large shopping centers have more competitors, the market share of the competition is smaller than that of the competitors of small shopping centers.

We rely on several theoretical frameworks to guide our empirical analysis. Real options theory is one of the most widely researched theories applied to the analysis of the irreversible investment decisions. The purchase of real estate includes embedded real options to alter the bundle of structural characteristics. Value derives from the flow of utility and/or rents from the existing property characteristics and from the right but not the obligation to alter the structure. The call (put) option is the right but not the obligation to increase (reduce) the scale of investment at a given location (McDonald and Siegel, 1986). Location is not subject to alteration: ownership of land confers the right but not the obligation to make changes to the structure. Dixit (1989) provides a simple theoretical framework, in which a fixed cost can be paid to go out of business and eliminate operating losses. If the factory is not operating, a

\footnotetext{
4 The term "irreversible" as used here simply means that any expansion or contraction is costly. Change in the number of stores is associated with relatively small costs of repositioning of walls. However, it requires costly renegotiation of leases. Change in GLA involves high construction costs. Both types of redevelopment involve disruption of existing retailing, adding to irreversibility.
} 
different cost can be paid to re-enter. Thus there are two states for the investment: operating or not operating. The former gives rise to the put option, which is in the money when variable costs are above revenues, while the latter has value for the call, which is in the money when value exceeds the cost of entry. ${ }^{5}$ Real options theory predicts that the increase in costs and (or) a decrease in expected revenue lower the value of call option but increase the value of put option.

Bulan, Mayer and Somerville (2009) point out that it can be difficult to distinguish redevelopment at the point in time when $\mathrm{NPV}=0$ from the redevelopment after a delay, when NPV $>0$. In real option theory, the NPV $=0$ point corresponds to a certainty world, where risk is zero and therefore the value of option to wait is zero. In contrast, when uncertainty is greater than zero the exercise takes place when NPV $>0$ and the option to delay is valuable; risk is important empirically. We show that a real options theoretical framework is more general than the NPV framework: i.e., the NPV rule is a special case of a barrier control policy. ${ }^{6}$

Our data are not well suited to distinguishing whether expansions and contractions take place when $\mathrm{NPV}=0$ or $\mathrm{NPV}>0$. We focus on factors triggering expansions and contractions without regard to whether the delay option has value: i.e., NPV $>0$ at the trigger point. However, our general framework allows us to separately consider some evidence supporting the role of uncertainty in delaying investment decisions.

\footnotetext{
5 The literature contains numerous empirical studies of the call option for housing: i.e., the option to tear down and rebuild a larger or more luxurious structure, or to substantially renovate. The tear down option is the subject of Rosenthal and Helsley (1994); Dye and McMillen (2007); Rosenthal (2008); Clapp and Salavei (2010); Clapp, Bardos and Wong (2011). Vacant land (zoned commercial and residential) has been studied by Quigg (1993); theory derives from the seminal work of Titman (1985). Commercial property call option exercise has been studied by Childs, Riddiough and Triantis (1996) and by Schwartz and Torous (2007). Empirical studies of put option have focused on mine openings and closings (Brennan and Schwartz 1985; Moel and Tufano 2002). The salient point here is the relatively high operating costs that can be saved by shutting down. Most housing and office properties would bear substantial operating costs (property taxes, insurance, security) even if shuttered, so an owner with an over-improved property has little choice but to wait for depreciation to reduce the value of the investment. Glaeser and Gyorko (2005) study asymmetrical investment decisions in housing.

${ }^{6}$ Dixit and Pindyck (1994, pp 139-40) point out that real options theory is relevant in a certainty world because the flexibility to delay a project has value. Certainty is a special case of the real options model: when risk approaches zero, then the NPV rule becomes the only relevant consideration. When risk is significantly greater than zero, then the NPV determinants (costs and revenues) are still relevant.
} 
We find that an increase in operating costs and a decrease in revenue lower the probability of expansion but increase the probability of contraction. Small shopping centers with large stores are more likely to provide greater variety of stores to customers while leaving the footprint in place. Large shopping centers with large stores adjust with both decreases of the footprint and increase in the number of store. This suggests that large shopping centers have greater flexibility in responding to changing market conditions. For small shopping centers the decision to change GLA is largely driven by potential revenue, while the decision to change the number of stores is mainly a function of cost. These results are consistent with the certainty case of classical real options model (e.g. Dixit (1989)).

If the value of option to delay is non-zero, then the trigger point for expansion will increase by the value of call option and the trigger point for contraction will decrease by the value of put option. Our results provide some support for the presence of non-negative put and call options. First, we find that both expansion and the contraction in GLA are less likely for large malls in MSAs with greater uncertainty about real estate prices. Second, Grenadier (1996) suggests that the value of both call and put option is reduced by competition: i.e., any value to the delay option is reduced as decision making is forced towards the NPV rule. An industry leader will exercise her option earlier than implied by the standard real options framework (e.g., Dixit's 1989 model) to reap the additional profits from leadership. We find support for Grenadier (1996) in our univariate analysis. Shopping centers that expand in GLA, but not the number of stores, have more competitors than the rest of the sample. Contractions in both GLA and number of stores have more competitors. The coefficient on number of competitors in multivariate analysis is only marginally significant in some models, but is of expected sign: the number of competitors reduces the value of option to wait and increases the likelihood of both expansion and contraction. The result is stronger for small shopping centers.

A third result supports the value of the delay option. Since small centers are likely to have greater idiosyncratic risk, real options theory predicts that they should wait 
longer before exercising expansion (call) or contraction (put) options. The data support this: the trigger points for small centers are less sensitive to changes in cost and revenue than those of large centers.

Lastly, we examine whether strategic deterrence (see, for example, Salvo (2010)) can explain shopping center renovation decisions. Shopping centers may expand in anticipation of competitive entry and contract in response to entry. We find support for this theory for large shopping centers: market share of competition reduces the likelihood of exercise of both call and put options. The result is stronger for expansions.

Overall, our hypotheses better explain contractions for large shopping centers and expansions for small shopping centers, suggesting that large shopping centers are above equilibrium size and small shopping centers are below equilibrium size.

The paper contributes to the literature in several ways. First, this paper provides first evidence on the determinants of redevelopment decisions for shopping centers. Second, our analysis uses a unique dataset of geographically diverse property level data that spans a ten year time period. Third, we simultaneously examine both expansions and contractions. Finally, our analysis focuses on redevelopment rather than new construction, which has received considerably more attention in the literature.

The paper proceeds as follows. The next section develops theory and testable hypotheses. Section 3 discusses the data. Section 4 presents univariate analysis. Multivariate analysis and robustness tests are discussed in Section 5, and the role of the delay option is explicitly addressed. Section 6 concludes the paper.

\section{Theoretical Background and Hypotheses}

A number of theories provide a framework for evaluating expansion and contraction decisions of US shopping centers. We include several relevant theoretical perspectives because the study of shopping center expansions and contractions is a new area of inquiry, without previous theory or empirical work that is directly 
relevant. $^{7}$ These theories provide a basis for identifying relevant explanatory variables and functional forms; these allow us to explore our database.

\subsection{Classical Option Exercise Model}

Dixit (1989) proposes a theoretical framework analyzing entry and exit decisions. Investment decisions are "irreversible" because they entail sunk costs. Suppose there is a project with operating cost $w$ per unit of time. The investment requires a sunk cost $k$ to enter. If the investment is made, the abandonment requires a one-time sunk cost $l$ to exit. $\rho$ is the rate of interest. $P$ is the revenue of the project per unit of time. If the firm believes that $P$ will be unchanged, it should invest if $P>w+\rho \cdot k=W_{H}$, where the right hand side is the annualized full cost of the investment. Similarly, if the project starts operation, it should be abandoned as soon as $P$ satisfies the following inequality: $P<w-\rho \cdot l=W_{L}$, where $W_{L}>0$. This is the NPV rule, which holds under certainty. The costs of investment provide the "irreversible" component to the investment decisions. ${ }^{8}$

In the NPV framework of Dixit (1989), it must be true that $0<W_{L}<P<W_{H}$. If $P$ falls below $W_{L}$ then the put option is rationally exercised and the supply of the product falls. ${ }^{9}$ If $P$ rises above $W_{H}$ then the call option is rationally exercised and the supply of the product increases. Most of our evidence focuses on the determinants of $P, W_{H}$ and $W_{L}$; as such, our evidence is consistent with this certainty model.

In this certainty model we have the following two equations:

$$
\text { Expand if : } P=(w+\rho \cdot k)=W_{H}
$$

\footnotetext{
${ }^{7}$ Cho and Shilling (2007) examines the real option applications on shopping center leases. Peng and Thibodeau (2011) examine the association between interest rate changes and capital expenditures for retail properties and find it to be insignificant.

${ }^{8}$ I.e., the firm can go in and out of business depending on $P$, but sunk costs imply that the firm may not enter the market even when it is profitable for existing firms, and may not exit even when price is below variable costs.

${ }^{9}$ A change in supply is one of the distinguishing features between real options and financial options. In this regard, real options are like stock warrants.
} 


$$
\text { Contract if }: P=(w-\rho \cdot l)=W_{L}
$$

Note that the NPV rule implies a band of inaction when price falls between the two trigger points; inaction arises because of the irreversible costs of expansion and contraction.

Dixit's model with a valuable option to delay

Equations (1) and (2) are special cases of Dixit's general model where risk is significantly greater than zero. When uncertainty is added in the form of a stochastic process for $P$, Dixit shows that a rational investor will follow a barrier control policy. $P_{H}$ and $P_{L}$ are two trigger values of investment and abandonment, where $P_{H}>P_{L}$. The investment should be made as soon as $P>P_{H}$ and abandoned as soon as $P<P_{L}$. The trigger value of investment is higher than the full cost because the value of delay is sacrificed when the real option is exercised.

$$
\text { Expand if : } P=W_{H}+D_{H}=P_{H}
$$

Here, $D_{H}>0$ is a measure of the value of the option to delay expansion because of uncertainty.

Similarly, the trigger value of abandonment is lower than the full cost when we consider that stochastic increases in price may make the project profitable in the future.

$$
\text { Contract if : } P=W_{L}-D_{L}=P_{L}>0
$$

Here, $D_{L}>0$ is a measure of the value of the option to delay contraction because of uncertainty.

The model assumes that $P$ is varying stochastically between the two barriers, $P_{L}$ and $P_{H}$. Changes in supply together with boundary assumptions ensure that price does not stray outside this range.

As a result, there is a "hysteresis" where an idle firm does not invest and an active firm does not exit when price is between $P_{H}$ and $P_{L}$. This area of inaction gets larger the higher the variance of the stochastic process and it responds in known ways 
to other parameters of the model.

In this study, we focus on how different characteristics affect the trigger values $W_{H}$ and $W_{L}$. Note that the NPV rule implies a band of inaction when price falls between the two trigger points; inaction arises because of the irreversible costs of expansion and contraction. Empirically it is difficult to distinguish whether exercise occurs when NPV=0 (equations (1) and (2)) or when NPV >0 (equations (3) and (4)) and the value of option to delay is positive. We provide limited evidence regarding the presence of option to delay in section 5.3.

For a given type of shopping center, ${ }^{10}$ we expect that an increase in $w$ and (or) a decrease in $P$ will lower the likelihood of expansion but increase the likelihood of contraction. These are the main empirical implications of our model.

In this paper, the dependent variables are constructed based on the change of GLA and number of stores. This allows us one measure of the cost of option exercise: it is costlier to change GLA than to change number of stores holding GLA constant. Construction costs for changing number of stores by moving internal partitions are not high. However, the cost of negotiating and renegotiating leases is high, and changing the number of stores disrupts existing business. Changing the amount of GLA, on the other hand, requires obtaining permits, pouring foundations and other construction costs as well as disrupting existing tenants. Thus, we hypothesize that both changes involve irreversibility but that the amount of irreversibility is greater for GLA change.

When shopping centers add or subtract GLA or stores they are exercising exchange options: i.e., they are exchanging the existing configuration of the real asset for another. ${ }^{11}$ A major cost of the exchange is the sacrifice of revenue from existing space or stores. We proxy this cost - i.e., a portion of $W_{H}$ and $W_{L}$ in equations (1) and (2) - with average size: GLA/store (store_size). I.e., we divide the total GLA in the center by the number of stores.

\footnotetext{
10 Shopping center types (e.g., community, regional or superregional) will be discussed below.

11 The internal configuration of the shopping center (i.e., mix of stores and placement of stores within the structure) has received some attention in the literature. See, for example,: Shulz and Stahl (1996), Carter (2009) and Benjamin, Boyle and Sirmans (1990 and 1992).
} 
Our store_size variable is in addition to the cost control we obtain by separating GLA change from store change. A third control for cost is provided by the enclosed dummy (enclosed). ${ }^{12}$ This allows us to evaluate evidence for the "demalling” trend: enclosed malls are said to reduce HVAC costs by converting to open air ("lifestyle" or “power”) centers. These shopping center types typically have less GLA and fewer stores.

Because store_size has GLA in the numerator and number of stores in the denominator, $^{13}$ its effect on GLA expansion will be different than its effect on store expansion. An increase in store_size increases the cost of GLA expansion because GLA is already relatively large; the exchange of the revenues from the existing GLA for the revenues from the new expanded GLA is likely to result in relatively small net gain. The reverse is true for expanding stores because the relatively large GLA can be more readily subdivided to allow for more stores. This reasoning leads to:

H1-Expansion: Store_size is negatively (positively) associated with the probability of expansion in GLA (number of stores). Enclosed is negatively associated with the probability of expansion in both GLA and number of stores.

H1-Contraction: Store_size is positively (negatively) associated with the probability of contraction in GLA (number of stores). Enclosed is positively associated with the probability of contraction in both GLA and number of stores.

We use ordered logit as the main empirical specification for testing our hypotheses, in which contraction is coded is -1 and expansion is coded as +1 .

Ordered logit implications of H1: Store_size is negatively (positively) associated with the dependent for GLA (number of stores). Enclosed is negatively associated with the dependent for both GLA and number of stores.

Our proxy for revenue (WATS) is based on the trade area of each shopping center: i.e., the geographical area providing most customers. ${ }^{14}$ The trade area will depend on the size and type of the shopping center as discussed below.

\footnotetext{
12 Enclosed is considered as one of the features of the shopping center design in Sirmans and Guidry (1993).

${ }^{13}$ Both are measured at the beginning of the period.

${ }^{14}$ WATS is the weighted average market share times household income within the trade area, per
} 
H2-Expansion: WATS is positively associated with the probability of expansion in GLA and number of stores.

H2-Contraction: WATS is negatively associated with the probability of contraction in GLA and number of stores.

Ordered logit implications: WATS is positively associated with the dependent, regardless of whether it is change in GLA or number of stores.

\subsection{Strategic Option Exercise - Grenadier}

Grenadier (1996) suggests that an industry leader tries to exercise the option earlier and reap the additional profits from leadership. This reduces the value of both call and put option. In a model with uncertainty (e.g., equations (3) and (4)), it moves the market towards the NPV point. The value of waiting ("hysteresis" in Dixit's model) is reduced.

Grenadier's theory implies that the number of competitors in the trade area is a relevant variable. I.e., the theory starts with the classic predictions; increased competition tends to set the $D_{H}$ and $D_{L}$ values in equations (3) and (4) to zero. The theory is based specifically on number of competitors (Compet_ttl). ${ }^{15}$

H3-Expansion: Number of competitors in the trade area is positively associated with the probability of expansion in GLA and number of stores.

H3-Contraction: Number of competitors in the trade area is positively associated with the probability of contraction in GLA and number of stores.

Ordered logit implications: offsetting effects imply insignificant coefficients regardless of whether we are evaluating changes in GLA or number of stores.

\subsection{Strategic Positioning}

We use the term "strategic positioning" to refer to expansions in anticipation of

square foot of GLA. See the Appendix for detailed calculations. Benjamin, Boyle and Sirmans (1992), Pashigan and Gould (1998) and Carter (2009) show a positive relation between sales per sq ft and rent per sq ft. See also Mejia and Benjamin (2002).

${ }_{15}$ Bulan, Mayer and Somerville (2009) use the number of competing residential projects as the measure of competition in their real option framework. 
competitive entry or contractions in response to entry. Game theory has yielded an extensive literature predicting strategic entry deterrence. In this branch of the literature, capacity expansion by an incumbent provides a credible threat for prospective entrants. By paying the cost of the expansion, the incumbent firm signals that they have the capacity to attract customers and the willingness to compete for market share.

Salvo (2010) develops a model applying strategic deterrence to a domestic monopolist (or a group of oligopolists) facing the threat of entry by a foreign firm. The domestic firms will expand production to satisfy the entire domestic market at a price point just below the price that would invite entry. Production will be expanded and contracted in response to demand shocks, but price will remain at the point of deterrence. This is relevant to shopping centers, where a center with relatively large amount of retail square footage can expand or contract retail lines (i.e., reconfigure existing space) in response to demand shocks. Positive demand shocks can lead to more GLA in an effort to saturate the market before competitors can gain entry. It takes a strong negative demand shock, perceived as permanent, to reach the abandonment point for GLA indicated by equation (2). ${ }^{16}$

Seminal theory related to entry deterrence is provided by Stahl (1982). Shopping centers are generated endogenously simply by introducing a fixed cost (or other non-convexity) into the transportation costs of consumers. It follows that the one stop shopping provided by shopping centers is valuable to consumers, and they are willing to pay more for it. In effect, shopping centers provide a valuable agglomeration economy for consumers. An immediate implication for our research is that potential revenue per square foot of retail space, $P$ in the model, increases with the size of the shopping center, and it will depend on bundling different types of goods together in a way that is valuable to consumers. For example, neighborhood centers might be anchored by a grocery store and include shoe repair (or other personal services) and a beauty salon. A larger community center might be anchored by a junior department

\footnotetext{
${ }^{16}$ Note that the $\rho l$ cost term can drive the abandonment point far below variable costs.
} 
store and include a pharmacy or home improvement center. In both cases, bundling is designed to increase $P$.

These agglomeration economies have been directly related to entry deterrence by Choi and Stefanadis (2006). The way in which a firm bundles its goods and services can provide significant barriers to competitive entry. They show the application to Microsoft's attempt to bundle software so as to discourage entry and GE's proposed merger with Honeywell. Here, we propose that shopping centers accomplish the same thing by building excess space that can be occupied by a changing mix of tenants. ${ }^{17}$

Another example of the strategic placement game is termed "predatory (or competitive) placement.” A center will enter, expand or reconfigure so as to cut off the flow of traffic to a competing center. I.e., by providing attractive intervening opportunities it obtains shoppers who formerly went to the rival center. This is just one example of the kind of market-filling placement discussed by Stahl (1982) and by Salvo (2010).

Empirically, we model strategic positioning with a variable measuring the market shares of rivals within the subject's trade area. ${ }^{18}$ We measure the market share of competing centers at the beginning of the observation period - i.e., before the subject decides to expand or contract. The logic of strategic positioning predicts a negative relationship between the market share of competitors within the trade area and the subject's probability of expansion, and a positive effect on the probability of contraction. The logic is that a prior space filling move by competitors, measured by market share, will limit the probability that the subject center will expand, and possibly force a contraction.

H4-Expansion: The market share of competitors (Compet_share) in the trade area is negatively associated with the probability of expansion in GLA and number of stores.

\footnotetext{
17 Smith and Hay (2005) have an interesting application to the agglomeration economies of independent owners ("streets" of independent retailers), shopping centers and "supermarkets," defined as a single store that offers many different product lines (e.g., butcher, baker, pharmacy and bank) within the store.

${ }^{18}$ Of course, we control for center type (e.g., regional or community).
} 
H4-Contraction: The market share of competitors (Compet_share) in the trade area is positively associated with the probability of contraction in GLA and number of stores.

Ordered logit implications: the market share of competitors in the trade area is negatively associated with the dependent, regardless of whether it is based on change in GLA or number of stores.

Note that H4 is differentiated from H3 by emphasizing market share, not number of competitors. Grenadier's theory (H3) deals specifically with number of competitors which drive the market away from oligopoly and towards strategic competition. On the other hand, H4 is based on agglomeration economies associated with market share.

It might be argued that number of competitors and market share of competitors are highly correlated, obviating the theoretical distinction between number of competitors and market share of competitors. In this case, the signs of the expected coefficients differentiate the two sets of hypotheses. Grenadier's theory predicts a positive sign on the expansion (call) option and it has no prediction for ordered logit, whereas strategic positioning predicts a negative association with the likelihood of expansion and on the ordered logit coefficient. Both predict a positive association with the likelihood of contraction.

\subsection{Alternative Hypotheses}

Our discussions with real estate professionals suggest a large number of hypotheses intended to explain expansion and contraction of shopping centers. Most of these are consistent with the above hypotheses. For example, one common hypothesis is that the trend away from enclosed malls and towards power centers or lifestyle centers is motivated by a desire for cost savings. Effective rental cost for tenants is their base rent, possibly a percentage of sales, and common area (CAM) charges. CAM can be a large part of total rent.

The desire to reduce CAM is just one aspect of the real options theories, $\mathrm{H} 1$ - H4; 
$w$ in the equations. Thus, we assert that the theoretical framework we have provided has richer implications than institutional hypotheses.

Our research is motivated by our unique database, allowing us to analyze expansion and contraction decisions. If the hypotheses $\mathrm{H} 1-\mathrm{H} 4$ yield incorrect or inconclusive predictions, then the data may suggest an alternative explanation supported by the professional retail literature. Any results supporting our hypotheses will be conservative since there are many impediments, such as delays in obtaining permits and neighborhood opposition, to shopping center owners acting in their best economic interests.

\section{Data}

We test our hypotheses using shopping center data from the Directory of Major Malls (directory or DMM thereafter). DMM reports shopping center characteristics for over 50 Metropolitan Statistical Areas (MSAs) for shopping centers with GLA of more than 250,000 square feet. We analyze 343 shopping centers in eleven MSAs. We choose MSAs that are included in the Case and Shiller price index and have the greatest number of shopping centers. ${ }^{19}$ We define that a shopping center is located in a particular MSA based on the Standards for Defining Metropolitan and Micropolitan Statistical Areas published by The Office of Management and Budget (OMB) in $2000 .^{20}$ We obtain directories for the following years: 1995, 2000, 2002 and $2005 .{ }^{21}$ For 223 (65\%) of shopping centers in our sample the first record appears in 1995 directory, for 76 (22\%) shopping centers the first record appears in 2000 directory and for remaining 44 (13\%) shopping centers - in 2002 directory. DMM reports name,

\footnotetext{
${ }^{19}$ We exclude the largest urban areas because downtown shopping centers have very different trade areas than suburban centers.

20 The 11 MSAs include (1) Boston-Cambridge-Quincy, MA-NH Metropolitan Statistical Area; (2) Charlotte-Gastonia-Concord, NC-SC Metropolitan Statistical Area; (3) Cleveland-Elyria-Mentor, OH Metropolitan Statistical Area; (4) Denver-Aurora, CO Metropolitan Statistical Area; (5) Las Vegas-Paradise, NV Metropolitan Statistical Area; (6) Minneapolis-St. Paul-Bloomington, MN-WI Metropolitan Statistical Area; (7) San Diego-Carlsbad-San Marcos, CA Metropolitan Statistical Area; (8) San Jose-Sunnyvale-Santa Clara, CA Metropolitan Statistical Area; (9) Seattle-Tacoma-Bellevue, WA Metropolitan Statistical Area; (10) Tampa-St. Petersburg-Clearwater, FL Metropolitan Statistical Area; and (11) Portland-Vancouver-Beaverton, OR-WA Metropolitan Statistical Area.

${ }^{21}$ We used the 2002 Directory to verify and revise variables from the 2000 Directory.
} 
location, design (open-air or enclosed), GLA, number of stores, site area, year opened, year of last renovation, etc. Some information, such as proposed expansion data, is self-reported by the managers and is considered subjective so we do not include it in our analysis.

For each shopping center we require at least 2 entries in directories so that we can determine whether an expansion or a contraction took place. It should be noted that some shopping centers are missing in some directories. Unless demolished before 2005, shopping centers with year opened before 1995 should be recorded in all four directories, shopping centers with year opened between 1995 and 2000 should appear in 2000, 2002 and 2005 directories, and so forth. We check all the observations to ensure that our results are not affected by survivorship bias. ${ }^{22}$ We focus on a stacked sample of two five-year time intervals: 1995-2000 and 2000-2005. In that way, we assume that each observation is independent, although one shopping center might be counted at most twice from 1995-2000 and 2000-2005. This assumption is reasonable because, even for a same shopping center, a stacked sample captures changes in the local market environment from one time period to the next.

We collect the latitudes and longitudes for all the shopping centers using a geographic information system (GIS). We then use Haversine formula to calculate the distances between shopping centers to surrounding census tracts and shopping centers to its competitors. Distances based on Haversine formula are great arc distances instead of road distances. Road distances vary with topographical conditions and methods of transportation and hence are more difficult to measure.

\section{Summary Statistics and Univariate Statistical Tests}

Table 1 describes the variables collected and calculated from the DMM, the US Census and S\&P. We use the latitude and longitude coordinates for each shopping center in the GIS system to define the trade area. Trade area is the geographical area

\footnotetext{
${ }^{22}$ We do not consider the change of ownership as a failed case. The directory assigns an identification number to each shopping center. The identification number does not change as the owner or name changes.
} 
from which most sales originate. The shopping center size and characteristics are major factors that delimit the trade area. An exact trade area is difficult to define because it relies on a complex of parameters such as uniqueness of retailer, variety of transportation, consumer perception, etc. Our classification comes principally from the International Council of Shopping Centers (ICSC thereafter), which is a leading global trade association of the shopping center industry. We define a shopping center as "large" if it has a GLA greater than 600,000 sq $\mathrm{ft}$ and number of stores greater than 40, which is the upper bound of a community center. The remaining centers are classified as "small". ${ }^{23}$ Similarly, a trade radius is assigned to each shopping center based on its type according to the ICSC standard. ${ }^{24}$

We use store size (scaled by 1,000 sq ft) and enclosed dummy as proxies for cost of renovation in H1. Competition is captured by the number of competitors within trade areas in order to address Grenadier's model of strategic option exercise, which is stated in H3-Expansion and contraction hypotheses. In addition, we calculate the average market shares for competitors within 5 miles to test H4-Expansion and contraction.

Table 2 shows the summary statistics of a pooled sample of five-year spans of 1995-2000 and 2000-2005..$^{25}$ Panel A includes continuous variables. Panel B presents statistics for dummy and MSA-level variables. Panels $\mathrm{C}$ through $\mathrm{E}$ compare the differences between two sub-samples: large and small shopping centers, expansions in GLA and contractions in GLA, expansions in number of stores and contractions in number of stores. Panel F compares each type of renovation with no change. Chi-square tests are used to test the independence of the sub-samples. To define expansion and contraction, we compare the first and the last observation of the sample

\footnotetext{
${ }^{23}$ ICSC clearly defines the range of GLA and number of stores, and trade areas for different types of shopping centers. The ICSC definition is different from Carter (2009). Some papers, such as Gatzlatt, Sirmans and Diskin (1994) and Carter and Vandell (2005) only focus on certain types of shopping centers.

${ }^{24}$ We apply 6 miles for community centers, 5 miles for power centers, 15 miles for regional shopping centers and 25 miles for super regional shopping centers. Note that community centers are power centers are classified as small shopping centers and regional and superregional malls are classified as large shopping centers.

25 Our results are similar when we use 5-year spans of 1995-2000 and 2000-2005, a 10-year span of 1995-2005 and a pooled sample of 5-year spans of 1995-2000 and 2000-2005.
} 
period and construct four renovation dummies, a dummy equal one if GLA increased (decreased) by $10 \%$ or more (GLA_exp and GLA_con, respectively) and zero otherwise; a dummy equal to one if the number of stores increased (decreased) by $10 \%$ or more (store_exp and store_con, respectively). All changes are calculated by comparing the first and the last observation of the time span; level variables are for the first year. For example, GLA and number of stores in Table 2 Panel A are from DMM 1995 for 1995-2000 time span observations and are from DMM 2000 for 2000-2005 observations. We focus on the first year we observe the shopping center so that prior shopping center characteristics can be allowed to predict subsequent renovation.

Table 2 Panels A and B show descriptive statistics for the sample. As shown in Panel A, an average shopping center in our sample is classified as a large shopping center with GLA of 612,115 sq ft and 76 stores. Mean shopping center increased GLA but decreased the number of stores, however the median shopping center did not change either GLA or the number of stores. The average store size is 11,950 square feet. WATS mean suggests that the potential revenue per sq $\mathrm{ft}$ from an average household within trade areas is about \$1.84. An average shopping center competes with twelve shopping centers in its trade area.

Table 2 Panel B shows that forty six percent of shopping centers are enclosed. Slightly more than half of our sample consists of large shopping centers. Our sample includes 113 expansions (55 in GLA and 53 in the number of stores) and 175 contractions (58 in GLA and 117 in the number of stores). In general, investors are equally likely to change GLA and number of stores for expansions but more likely to change number of stores for contractions as suggested by much greater proportion of store contractions in all the sub-samples. The imbalance in the irreversible investments indicates that investors are ambitious in expansion by changing the shopping center footprint but conservative in contraction by only altering the tenant profile. This phenomenon could be explained by strategic deterrence because, once the scale-indication investment is made, it has value in deterring competitive entry. 
I.e., it poses a credible threat of high attractive power (agglomeration economies) and low prices due to scale economies.

MSA-level variables show that our observations are fairly equally distributed across eleven MSAs. Comparatively, the distributions of renovations show more variations. For example, some MSAs, such as Minneapolis and Boston have a greater percentage of expansions and contractions. Case-Shiller growth rate (growth5) and standard deviation (std5) variables are used to test the basic prediction of uncertainty version of Dixit's model. They are available only at MSA level. Because we pool two five-year sample periods, we choose the annualized Case-Shiller growth rate and standard deviation in the middle year of the first and last observations. We use the alternatives of 1-year, 3-year and 5-year average within the middle year. As a result, each MSA has 2 observations for annualized growth and standard deviation.

Panel C compares sub-samples of small and large shopping centers. It is likely that many large shopping centers are above equilibrium size while many small shopping centers are below equilibrium. As a result, large shopping centers might be more likely to contract and small shopping centers might be more likely to expand. Therefore, we analyze large and small shopping centers separately. T-test and Wilcoxon test are used to test the differences in sample mean and median of continuous variables, respectively. Chi-square test is used to test the independence of two sub-samples for binary variables.

In Panel C, an average small shopping center has GLA of 346,000 sq ft and 33 stores and an average large shopping center has GLA of 847,000 sq ft and 113 stores. A significantly larger store size of small shopping centers, together with a greater fraction of store contractions in large shopping centers, is consistent with the current trend of power center conversions. ${ }^{26}$ Large shopping centers have more competitors and capture greater market share so they have smaller average weighted average market share of competitors within 5 miles (compet_share). A proxy for revenue per

\footnotetext{
${ }^{26}$ Power centers became quite common in recent years. A power center usually refers to a shopping center with 200,000 to 800,000 square feet of gross leasable areas that contains three or more big-box retailers or department stores and a number of smaller retailers. Movie center conversion refers to the renovation in which the shopping center owners take the movie center out and add more retailers.
} 
sq ft, WATS, is significantly greater for large shopping centers than small shopping centers. $^{27}$ The difference of WATS between small and large shopping centers is consistent with the retail agglomeration economies theories in Ghosh (1986), Stahl (1982) and West, Von Hohenbalkon and Kroner (1985). Large shopping centers are much more attractive to shoppers, so they have higher sales volume per sq $\mathrm{ft}^{28} \mathrm{~A}$ smaller store_size together with a higher WATS of large shopping centers is also consistent with Carter (2009) and Pashigan and Gould (1998) that smaller stores tend to have higher sales and rent per sq ft. Chi-square tests show that there is a significantly higher proportion of enclosed malls among large shopping centers. Large shopping centers are more likely to renovate except for store expansion. In conclusion, the differences in characteristics between small and large shopping centers highlight the importance of controlling for shopping center type in the regression analysis.

Table 2 Panels $\mathrm{D}$ and $\mathrm{E}$ examine sub-samples by type of renovation. Our hypothesis, H1-Expansion, is supported by a significantly smaller store_size of GLA-expansion shopping centers when compared to shopping centers that experienced contraction (Panel D). Shopping centers that have large store sizes as measured by GLA/store face lower costs from GLA contraction. ${ }^{29}$ Turning to expansion in number of stores compared to contraction in number of stores (Panel E), we expect that the cost of exercise is reversed: it is relatively inexpensive to expand stores (expensive to contract) when store size is large. Panel E confirms that this is a significant effect, supporting H1. Enclosed proportions support hypothesis 1 only for expansion in number of stores but not expansion in GLA because the proportion of enclosed shopping centers for GLA expansions is not significantly greater than for GLA contractions. This might be explained by the agglomeration economies (high rent per square foot) in enclosed shopping centers. ${ }^{30}$ These results provide no support for the "demalling” trend reported in the press; in our experience, this occurs when

\footnotetext{
${ }^{27}$ We present both the absolute value and the log value of WATS. While we use log value of WATS in regressions, the results are similar when we use absolute value.

${ }^{28}$ Benjamin, Boyle and Sirmans (1992) also conclude that the larger the centers, the higher the rents.

${ }^{29}$ This is an exchange option, so revenue loss from any change is part of the cost of exercise.

30 Sirmans and Guidry (1993) find that enclosed shopping centers have higher rents because they provide more variety and thus have higher ability to attract customers.
} 
few new centers are enclosed.

H2-Expansion and H2-Contraction predict that proxy for revenue per sq $\mathrm{ft}$ is positively (negatively) associated with the probability of expansion (contraction) in GLA and number of stores. As shown in Panels D and E, GLA-expansion and store-expansion shopping centers WATS is greater than that for the full sample, which is consistent with H2-Expansion. Although we do not find a smaller WATS in store-contraction shopping centers, WATS in GLA-contraction shopping centers is smaller than for the full sample consistent with H2-Contraction. Consistent with H3-Expansion and H3-Contraction, we find that number of competitors is greater in each type of renovations than the whole sample. Because of the offsetting effects of number of competitors (H3), the mean and median are not significantly different between expansion and contraction sub-samples in both cases. The coefficients of compet_share provide little evidence on the strategic positioning as most of the tests on mean and median differences are insignificant.

The offsetting effects predicted by H3 highlight the importance of comparing each type of renovation with no change in Panel F. Consistent with H1, store_size is significantly negative in GLA expansion and store contraction and significantly positive in store expansion. Consistent with H1, proportion of enclosed shopping centers is higher in store contraction than in no change sub-sample. A higher proportion of enclosed shopping centers in the GLA-expansion sub-sample seems to contradict $\mathrm{H} 1$ but can be explained by agglomeration economies. Although WATS is insignificantly different for contractions when compared to no change, it is significantly higher for expansions on both GLA and number of stores as predicted in H2. Competition is higher for both expansions and contractions than no change sub-sample, supporting H3. Lastly, market share (compet_share) does not differ for the sub-samples.

Overall, Panels D and E suggest that renovation decisions on GLA and number of stores should be examined separately. The renovation decisions on GLA and number of stores might be explained by different factors in different ways. For 
example, store_size is significantly smaller in GLA-expansion than GLA-contraction but significantly greater in store-expansion than store-contraction. In addition, WATS difference is significant in GLA change but not in store change sub-samples.

\section{Multivariate Results}

In this section we perform multivariate tests of our hypotheses. We employ three types of logistics regressions: ordered, multinomial and simple logit. ${ }^{31}$ Ordered and multinomial logit allow us to jointly consider expansions and contractions. The dependent variable in these models equals -1 for contractions, +1 for expansions and 0 otherwise. Ordered logit is the most appropriate model for our analysis because there is a natural order to our dependent variable: when put option is in the money the call option is out of the money and vice versa. Similarly, even when the value of option to wait is zero, $W_{H}$ and $W_{L}$ are not equal. Therefore, when a shopping center hits upper bound $W_{H}$ it will be above lower bound $W_{L}$. Moreover, the results are easy to interpret. Multinomial model lifts some restrictions by allowing for asymmetric effect of explanatory variables on decision to expand or contract. However, multinomial model does not consider the order of the dependent variable, and it assumes independence of irrelevant alternatives (IIA).

\subsection{Multivariate analysis - Ordered logit}

Table 3 shows ordered logistic regression for the stacked sample of 1995-2000 and 2000-2005. Since changing number of stores is less costly than changing the amount of GLA, we separately analyze change in GLA and change in the number of stores to better control for cost of irreversible decision. The dependent variable in the analysis of changes in GLA is gla_reno and equals -1 if GLA decrease by $10 \%$ or more and +1 if GLA increase by $10 \%$ or more during the observation period; and zero

\footnotetext{
31 Prior literature also used hazard models to examine the determinants of time between renovations (Bulan, Mayer and Somerville (2000)). Our data is not well suited for such tests because we observe a shopping center only at three points during a ten year interval. Moreover, the Directory of Major Malls does not provide reliable data on the year built and year since last renovation, variables essential to hazard analysis.
} 
otherwise. The store_reno variable is constructed in the same manner for store size.

In Model 1, we focus on testing the implications of irreversible investment theory (hypotheses 1 and 2). To test hypothesis 1, we include two measures of cost in our model: store_size and enclosed. We expect negative association between these variables and gla_reno, and positive association with store_reno. To test hypothesis 2, we include WATS, which proxies for revenue per square foot. We expect positive association of WATS with both gla_reno and store_reno. We allow for different effect for large and small shopping centers by including large dummy and interacting it with WATS and store_size. All continuous variables are standardized to the mean of zero and the variance of one. Therefore, the coefficients show change in the likelihood of expansion or contraction given a one standard deviation change in explanatory variable. The marginal effects of each coefficient for large shopping centers are shown at the bottom of Table 3 .

We find that for both small and large shopping centers the sign of the coefficient on store_size is as predicted by hypothesis 1: negative for gla_reno and positive for store_reno. However, for large shopping centers this coefficient is significant only in gla_reno regression while for small shopping centers it is significant only in store_reno regression. ${ }^{32}$ When stores are large, the cost of developing additional GLA is high, whereas the cost of reconfiguring GLA for additional stores is relatively small. The results suggest that small shopping centers are more likely to increase the number of stores the bigger the initial store size, whereas this variable has no significant effect on change in GLA. I.e., costs and benefits are such that small shopping centers with big stores optimize by leaving their footprint unchanged while subdividing the space so as to give customers a greater variety of stores. Large shopping centers, on the other hand, are more likely to decrease GLA as store size gets bigger, reducing their footprint. For large shopping centers, the response of number of stores to the store size variable is the same as small shopping centers. Thus, large shopping centers adjust with both GLA decreases and with store increases whereas small shopping

\footnotetext{
${ }^{32}$ See marginal effects for large shopping centers in Table 3.
} 
centers only use the latter. These results are consistent with hypothesis 1 . Although the coefficient on the enclosed dummy is not significant in either model, the sign is negative and consistent with $\mathrm{H} 1$ that enclosed malls are less likely to expand and more likely to contract.

We find support for hypothesis 2. For small shopping centers a proxy for revenue per square foot, WATS, is positive and significant in gla_reno regression and is positive but insignificant in store_reno regression. ${ }^{33}$ Combined with the findings for store_size, this suggests that for small shopping centers the decision to change GLA is largely driven by potential revenue, while the decision to change the number of stores is largely a function of cost. For large shopping centers both the decision to increase GLA and the decision to increase number of stores is positively associated with WATS, suggesting that expected revenue is an important consideration for expansion decisions. Note that for large shopping centers the decision to change GLA is determined by both costs and revenue (as suggested by negative coefficients on store_size and WATS). However, only expected revenue proxy (WATS) and not the cost proxies (store_size and enclosed) are significant at explaining the decision to change number of stores for large shopping centers. Overall, the results suggest that large shopping centers have more room to maneuver than small shopping centers and respond to changing market conditions by altering both number of stores and the footprint of the shopping center.

Model 2 tests whether predictions of Grenadier's theory can help explain the decision to redevelop. We include compet_ttl and its interaction with large to Model 1. We find that total competition does not explain decision to change GLA or number of stores for either small or large shopping centers, rejecting hypothesis 3 . The rest of the results remain robust to inclusion of these variables.

To tests hypothesis 4, we include the average of the WATS of competitors within 5 miles of the subject shopping center (compet_share) and interaction of compet_share with large dummy (see Model 3). Since compet_share and compet_ttl

\footnotetext{
${ }^{33}$ Note that the p-value is .26 , suggesting that an increased sample size will produce a significant positive sign.
} 
are likely correlated, we exclude compet_ttl from Model 3. We find support for hypothesis 4 only for large shopping centers in store_reno regression. The coefficient on compet_share is negative and significant; this suggests that a larger market share of competitors increases the probability of contraction of the number of stores. This follows from theory which says that a larger share for competitors shrinks the customer base and reduces optimal size. The rest of the results are unaffected with an exception of the negative coefficient on enclosed dummy becoming significant in store_reno, providing further support for hypothesis 1.

Table 4 shows separate analysis for large and small shopping centers. For large shopping centers, positive coefficient on store_size becomes significant in store_reno regression (Models 1 and 2), and enclosed dummy becomes significant in Model 2, providing support for hypothesis 1. For small shopping centers results in Table 4 are similar to those in Table 3.

Overall, we find the decision of a shopping center to expand or contract is best explained by classical theory of irreversible reinvestment, rather than by number of competitors and the market share of the competition. ${ }^{34}$

\subsection{Multivariate analysis - multinomial and simple logit}

So far our analysis employed ordered logistic regression. The advantage of this approach is that we were able to simultaneously consider expansions and contractions and account for natural ordering of these decisions. However, ordered logit does not allow for asymmetric affect of explanatory variables. Moreover, the IIA assumption is required. In this section, we replicate Table 4 using multinomial logistic regression, which produces separate coefficient for expansions and contractions, while considering these decisions simultaneously.

Table 5 suggests that the effect of all explanatory variables on gla_reno and store_reno differs for expansion and contraction decisions. One new result in Table 5 is that large shopping centers are more likely to contract: the total effect for large

\footnotetext{
${ }^{34}$ Section 5.4 discusses the evidence supporting the presence of option to wait.
} 
dummy is positive and significant for contractions for both gla_reno and store_reno regressions in all three models. However, the total effect for large dummy is not significant for expansions, suggesting that large shopping centers are equally likely to expand as small shopping centers. Interestingly, none of the variables are significant in explaining contractions of small shopping centers in Table 5. At the same time, the results for expansions of small shopping center in multinomial logit (Table 5) are very similar to results using ordered logit (Table 4): revenue proxy WATS is increasing the likelihood of expansion in GLA and cost proxy store_size is increasing the likelihood of expansion in number of stores. This suggests that the significance in ordered logit comes from the relation of WATS and store_size with expansion but not the contractions of the small shopping centers. Similarly, for large shopping centers we find that there is more significance in expansion rather than contraction models (see net effects for WATS and store_size). Overall, multinomial logit indicates that theory of irreversible investment better explains contraction decisions of large shopping centers and expansion decisions of small shopping centers, suggesting that large shopping centers are above equilibrium size and small shopping centers are below equilibrium size.

Table 6 performs multinomial logit analysis separately for large and small shopping centers. For large shopping centers WATS and store_size are highly significant in explaining contraction in both GLA and number of stores in the direction predicted by hypothesis 1 . WATS decreases the likelihood of GLA and number of store contractions, suggesting that higher expected revenue makes the shopping center less likely to contract. Consistent with Hypothesis 2, store_size increases the probability of contraction on GLA but decreases the probability of contraction on number of stores. Total competition becomes marginally significant at 9\% in the GLA contraction model: a greater number of competitors makes contraction more likely. This supports hypothesis 3.

Interestingly, for large shopping centers none of the variables are significant in the expansion on GLA model, although the p-values are all below 30\% suggesting 
that a larger sample size might result in more power. In Table 5 WATS is positive but WATS for large shopping centers is much higher than small shopping centers so the effect becomes not as prominent as in general model.

In Models 2 and 3, the negative coefficient on store_size becomes significant in GLA expansion model, supporting hypothesis 1: large shopping centers with high operating costs are less likely to expand. Store_reno regressions for expansions provide support for hypotheses 1 and 2: enclosed malls are less likely to expand number of stores; shopping centers with high expected revenue are more likely to expand number of stores as suggested by positive coefficient on WATS. We also find support for hypothesis 4: higher market share of competitors decreases the likelihood of expansion on the number of stores.

The decision to contract for small shopping centers is explained only by number of competitors - greater number of competitors forces small shopping centers to increase the probability of contraction (Table 6, Panel B). The decision to expand for small shopping centers is associated with more variables: expansion in GLA is positively associated with WATS and compet_ttl; expansion in number of stores is positively associated with store_size. Overall, multivariate logit shows that for large shopping centers our hypotheses better explain contractions while for small shopping centers our hypotheses better explain expansions, supporting our contention that large shopping centers are above equilibrium and small shopping centers are below equilibrium.

\subsection{Evidence for the value of the option to delay}

Equations (3) and (4) apply to the more realistic assumption of a stochastic process for price, $P$. In this case, the higher the variance of the process, the higher the "wedge" between the NPV rule and the real option rule. This wedge is represented by $D_{H}$ (expansion option) and $D_{L}$ (contraction option). The purpose of this section is to summarize the evidence pertaining to the role of uncertainty in adding value to the option to delay. 
Our data are not well suited to directly test the predictions of real options theory of positive association of uncertainty and the value of options to expand and contract because we do not have a property level measure of uncertainty. However, we are able to provide some limited evidence that suggests the presence of option to wait to renovate. First, we re-estimate models in Tables 3 and 4 replacing MSA dummies with MSA level measures of drift (growth5) and variance (std5) of house prices obtained from Case and Shiller Indexes. We find that for large centers the coefficient on std5 is negative and significant in GLA models, suggesting that higher uncertainty about real estate prices delays redevelopment. The coefficient on growth5 is positive but not significant for large centers in any of the models. The coefficient on neither variable is significant for small centers.

Second, as discussed earlier, we find some support for Grenadier's model: greater number of competitors increases the likelihood of contraction, especially for small centers. Grenadier's model assumes that the value of option to delay is non-negative and that competition reduces the value of this option forcing exercise close to the NPV=0 point: $D_{H}$ and $D_{L}$ approach 0 in equations (3) and (4). Therefore, we interpret this evidence as providing weak support for the value of the delay option.

The most persuasive evidence for a valuable delay option is contained in Table 4. Compare the sensitivity to WATS for large centers to small centers. There is no significant difference for GLA renovation, but store renovation shows a substantial and statistically significant difference. A one standard deviation increase in WATS produces a .94 increase in renovation for large centers, versus a .39 increase for small centers. I.e., small shopping centers have trigger points that are less responsive by a factor of .5 to changes in revenue per square foot. The t-value for the difference between .94 and .39 is 2.63 .

Now consider another important driver of the trigger points, store_size. For the decision to renovate GLA, a standard deviation in store size is associated with a statistically significant -2.97 change for large centers, versus an insignificant -.024 for small centers. A similar comparison for store renovation show substantially less 
sensitivity for small centers: 1.62 for large versus .33 for small. The t-value for this difference is 2.55 .

We claim that this is persuasive evidence because small centers are likely to have substantially more idiosyncratic risk than large centers, and higher risk means less sensitivity to revenues and costs. Higher idiosyncratic risk is intuitively plausible because competitive entry and exit is easier for small centers; therefore, a new entrant in the trade area can greatly alter profitability.

A large stream of research in the finance literature demonstrates that small firms face higher idiosyncratic risk than large firms. Brandt, Brav, Graham and Kumar (2010) find that idiosyncratic volatility monotonically decreases in firm size. Fu (2009) documents that $40 \%$ of stocks with the highest idiosyncratic volatilities account for only $9 \%$ of the total market capitalization. Campbell, Lettau, Malkiel and Xu (2001) conclude that many small firms entering the market cause large increase in firm-level variance.

To summarize our evidence for the delay option based on Table 4:

1. Small centers are likely to have more idiosyncratic risk;

2. Greater risk implies larger values for $D_{H}$ and $D_{L}$;

3. Therefore, small centers are predicted to be less sensitive to NPV determinants such as revenues and costs, and this is what we find in Table 4.

\subsection{Robustness tests}

In this section we perform several robustness tests. We estimate simple logit regressions, which consider the decision to expand and contract independently. In terms of Dixit's theory, this is supported if the call option is deep out of the money when the put option is in the money, and vice versa. As a robustness test, simple logit avoids the IIA assumption made by multinomial logit: simple logit assumes the independence of two decisions whereas multinomial logit assumes dependence.

Tables 7 and 8 show simple logit results. The dependent variable in the first column is gla_exp, which equals one if GLA increased by $10 \%$ or more and zero 
otherwise. Note that contractions are assigned the value of zero in this model. Similarly, in gla_con model, decrease in GLA of more than $10 \%$ is assigned a value of one and the rest of the observations, including expansions, are coded as zeros. The results in Table 7 are similar to those in Table 5, suggesting that our inference is not affected by whether decision to expand and contract are considered as independent or jointly determined. The results in Table 8 differ just slightly from the results in Table 6: coefficients on WATS and store_size in GLA expansion regression become significant in all models, providing further support for hypotheses 1 and 2.

We perform several other robustness tests. First, we change the threshold for major renovation from $10 \%$ to $5 \%$ and $3 \%$. Our results remain robust to these alternative definitions of expansions and contractions. Second, we perform analysis on continuous measures of renovation: percent change in GLA and percent change in number of stores and obtain similar results. We report results using $10 \%$ in the body of the paper because this high threshold allows us to focus on major renovations and minimizes the influence of noisiness in the data.

\section{Conclusions}

We find the decision to expand or contract is best explained by standard theory of irreversible investment; Dixit's (1989) model is particularly relevant because it applies to both expansions and contractions. Shopping centers with large operating costs are less likely to expand and are more likely to contract. Higher expected revenue increases the likelihood of expansion and decreases the likelihood of contraction. For small shopping centers the decision to change GLA is largely driven by potential revenue, while the decision to change the number of stores is largely a function of cost.

We find weak support for Grenadier's theory that large number of competitors reduces the value of option to wait and increases the likelihood of both expansion and contraction. The result is stronger for small shopping centers. The market share of competitors reduces the likelihood of increasing the number of stores as suggested by 
the theory of strategic positioning (Salvo, 2010).

Our hypotheses best explain contraction decisions of large shopping centers and expansion decisions of small shopping centers, suggesting that large centers appear to be above equilibrium size and small shopping centers are smaller than equilibrium. Our results are robust to estimating expansions and contractions jointly or independently.

We find some support for a significant role for the option to delay investment because of risk: i.e., the call and put trigger points are wedged apart by the value of the delay option. The most persuasive evidence is that small centers are less sensitive to the revenue and cost determinants of risk. Small centers are likely to have more idiosyncratic risk than large centers. Dixit's (1989) theory implies that more risk is associated with a bigger wedge, and therefore with less willingness to exercise, and this is what we find.

\section{Appendix: Calculation of WATS}

To test the implications of potential revenue on the expansion and contraction decision (Hypothesis 2) we first calculate WAMS (weighted average market share within a trade area) as the sum of income adjusted gravity potential for each tract in shopping center's trade area. We assume the following trade area for different types of shopping centers: a 40 mile radius for that superregional shopping centers, a 20 mile radius for regional shopping centers, and a 10 mile radius for community.

We calculate gravity potential for each tract $\mathrm{j}$ in each shopping center's i trade area.

$$
\text { Gravity potential }_{\mathrm{ij}}=\mathrm{GP}_{\mathrm{ij}}=\frac{\frac{\mathrm{GLA}_{\mathrm{i}}}{\text { distance }_{\mathrm{ij}}}}{\sum_{\mathrm{i}=1}^{N} \frac{\mathrm{GLA}_{\mathrm{i}}}{\text { distance }_{\mathrm{ij}}}}
$$

where distance is the distance between the shopping center and the center of the tract. If the distance is less than 1 mile, then it is set to 1 mile. Otherwise the distance equals the actual distance. $N$ is the number of shopping centers competing for 
tract $j$. For example, when there are 3 shopping centers (Shopping center 1, Shopping center 2, and Shopping center 3) and 3 tracts (Tract A, Tract B and Tract C), and Shopping centers 1 and 2 compete for Tract A, then the formula for the gravity potential for Shopping center 1 Tract A is as follows:

$$
\text { Gravity potential }_{1 \mathrm{~A}}=\mathrm{GP}_{1 \mathrm{~A}}=\frac{\frac{\mathrm{GLA}_{1}}{\text { distance }_{1 \mathrm{~A}}}}{\frac{\mathrm{GLA}_{1}}{\text { distance }_{1 \mathrm{~A}}}+\frac{\mathrm{GLA}_{2}}{\text { distance }_{2 \mathrm{~A}}}}
$$

In this example there are only two shopping centers competing for tract A's sales. So the denominator should have only two terms. Note that gravity potentials for each tract will add up to one. Next, we adjust gravity potential by tract's scaled net income.

$$
\text { Income Adjusted } \mathrm{GP}_{\mathrm{ij}}=\mathrm{GP}_{\mathrm{ij}} *\left(\frac{\mathrm{TI}_{\mathrm{j}}}{\sum_{\mathrm{j}=1}^{\mathrm{Mi}} \mathrm{TI}_{\mathrm{j}}}\right)
$$

$\mathrm{TI}_{j}$ is the total income for tract $j$ from 2000 decennial Census. $\mathrm{M}_{i}$ is the number of tracts in shopping center i's trade area. If in our example Shopping center 1 is competing for all three tracts (Tract A, B and C), then Income Adjusted $G P_{1 \mathrm{~A}}$ is calculated as follows.

$$
\text { Income Adjusted } \mathrm{GP}_{1 \mathrm{~A}}=\mathrm{GP}_{1 \mathrm{~A}} *\left(\frac{\mathrm{TI}_{\mathrm{A}}}{\mathrm{TI}_{\mathrm{A}}+\mathrm{TI}_{\mathrm{B}}+\mathrm{TI}_{\mathrm{C}}}\right)
$$

WAMS is then calculated as the sum of Income Adjusted $G P_{i j}$ across all tracts in shopping center i’s trade area:

Weighted Average Market Share ${ }_{\mathrm{i}}=\mathrm{WAMS}_{\mathrm{i}}=\sum_{j=1}^{M_{i}}$ Income Adjusted GP $_{\mathrm{ij}}$ In our example, WAMS for Shopping center 1 is calculated as follows: 
WAMS $_{1}=$ Income Adjusted GP ${ }_{1 \mathrm{~A}}+$ Income Adjusted GP $\mathrm{PB}_{1 \mathrm{~B}}+$ Income Adjusted GP $\mathrm{P}_{1 \mathrm{C}}$

Our proxy for potential revenue per sq $\mathrm{ft}$ for a shopping center, WATS, is WAMS multiplied by population weighted household income in the trade area and then divide by its GLA. WATS simply measures how much per sq $\mathrm{ft}$ does an average household within the trade area will spend in shopping center $i$. 


\section{References}

Benjamin, J.D., G.W. Boyle, and C.F. Sirmans. 1990. Retail Leasing: The Determinants of Shopping Center Rents. Journal of the American Real Estate and Urban Economics Association 18: 302-12.

_. 1992. Price Discrimination in Shopping Center Leases. Journal of Urban Economics, 1992, 32: 299-317.

Brandt, M., A. Brav, J. Graham and A. Kumar. 2010. The Idiosyncratic Volatility Puzzle: Time Trend or Speculative Episodes? Review of Financial Studies 23: 863-899.

Brennan, M. J., and E. S. Schwartz. 1985. Evaluating Natural Resource Investments, Journal of Business 58, 2: 135-157.

Bulan, L., C. Mayer, and C.T. Somerville. Irreversible Investment, Real Options, and Competition: Evidence from Real Estate Development. Journal of Urban Economics, 2009, 65: 237-51.

Campbell, J., Lettau, M., Malkiel, B., Xu, Y., 2001. Have Individual Stocks Become More Volatile? An Empirical Exploration of Idiosyncratic Risk. Journal of Finance 56, 1-43.

Carter, C.C. 2009. What We Know about Shopping Centers. Journal of Real Estate Literature 17: 165-180.

Carter, C.C. and K.D. Vandell. 2005. Store Location in Shopping Centers: Theory and Estimates. Journal of Real Estate Research 27: 237-65.

Childs, P., T. Riddiough and A. Triantis. 1996. Mixed Uses and the Redevelopment Option. Real Estate Economics 24: 317-339.

Cho, H. and J.D. Shilling. 2007. Valuing Retail Shopping Center Lease Contracts. Real Estate Economics 35: 623-49.

Choi, J.P. and C. Stefanadis. 2006. Bundling, Entry Deterrence, and Specialist Innovators, Journal of Business 79: 2575-2594.

Clapp, J.M., K. S. Bardos and S.K. Wong. 2011. Empirical Estimation of the Option Premium for Residential Redevelopment. WP.

Clapp, J.M. and K. Salavei. 2010. Hedonic pricing with redevelopment options: A new approach to estimating depreciation effects. Journal of Urban Economics 67:362-377.

Dixit, A. 1989. Entry and Exit Decisions under Uncertainty. Journal of Political Economy 97: 620-638. 
Dixit, A.K. and R.S. Pindyck. 1994. Investment under Uncertainty. Princeton University Press: Princeton, N.J.

Dye, R.F. and D.P. McMillen, 2007. Teardowns and Land Values in the Chicago Metropolitan Area, Journal of Urban Economics 61: 45-63.

Fanning, S. 2005. Market Analysis for Real Estate. Appraisal Institute, Chicago, IL.

Fu, F. 2009. Idiosyncratic Risk and the Cross-section of Expected Stock Returns. Journal of Financial Economics 91: 24-37.

Gatzlaff, D.H., G.S. Sirmans, and B.A. Diskin. 1994. The Effect of Anchor Tenant Loss on Shopping Center Rents. Journal of Real Estate Research 9: 99-110.

Ghosh, A. 1986. The Value of a Mall and Other Insights from a Revised Central Place Model. Journal of Retailing 62: 79-97.

Glaeser, E. and J. Gyourko. 2005. Urban decline and durable housing. Journal of Political Economy. 113: 345-375.

Grenadier, S. 1996. The Strategic Exercise of Options: Development Cascades and Overbuilding in Real Estate Markets. Journal of Finance 51: 1653-1679.

McDonald, R. and D. Siegel, 1986. The Value of Waiting to Invest. Quarterly Journal of Economics 101, 707-727.

Mejia, L.C. and J.D. Benjamin. 2002. What Do We Know About the Determinants of Shopping Center Sales? Spatial vs. Non-Spatial Factors. Journal of Real Estate Literature 10: 3-26.

Moel, A. and P. Tufano. 2002. When are Real Options Exercised? An Empirical Study of Mine Closings. Review of Financial Studies. 15: 35-64.

Pashigan, B.P. and E.D. Gould. 1998. Internalizing Externalities: The Pricing of Space in Shopping Malls. Journal of Law and Economics, XLI, 115-42.

Peng, L. and T.G. Thibodeau. 2011. Interest Rate and Investment under Uncertainty: Evidence from Commercial Real Estate Capital Expenditures. WP.

Quigg, L. 1993. Empirical Testing of Real Option-Pricing Models. Journal of Finance 48: 621-640.

Rosenthal, S. 2008. Old Homes, Externalities, and Poor Neighborhoods: A Dynamic Model of Urban Decline and Renewal, Journal of Urban Economics, 63: 816-840.

Rosenthal, S. and R. Helsley. 1994. Redevelopment and the Urban Land Price Gradient. Journal of Urban Economics, 35: 182-200.

Salvo, A. 2010. Inferring market power under the threat of entry: the case of the 
Brazilian cement industry. RAND Journal of Economics 41: 326-350.

Schwartz, E. and Torous W. 2007. Commercial Office Space: Testing the Implications of Real Options Models with Competitive Interactions. Real Estate Economics 35: $1-20$.

Schulz, N. and K. Stahl. 1996. Do Consumers Search for the Highest Price? Oligopoly Equilibrium and Monopoly Optimum in Differentiated-Products Markets. RAND Journal of Economics 27: 542-562.

Sirmans, C.F. and K.A. Guidry 1993. The Determinants of Shopping Center Rents. Journal of Real Estate Research, 8: 107-15.

Smith, H. and D. Hay. 2005. Streets, Malls, and Supermarkets. Journal of Economics \& Management Strategy 14: 29-59.

Stahl, K. 1982. Location and Spatial Pricing Theory with Nonconvex Transportation Cost Schedules. The Bell Journal of Economics 13: 575-582.

Titman, S. 1985. Urban Land Prices Under Uncertainty. American Economic Review 75: 505-514.

West, D.S., B. Von Hohenbalken, and K. Kroner. 1985. Tests of Intraurban Central Place Theories. The Economic Journal 95: 101-17. 
Table 1: Variable Definition

This table summarizes variable definitions. Shopping center characteristics and renovations are estimated and tracked from Directory of Major Malls (DMM). Trade areas are delineated from the geographic information system (GIS). Demographic data are collected from the US Census Bureau.

\begin{tabular}{|c|c|c|}
\hline $\begin{array}{l}\text { Variable } \\
\text { Name }\end{array}$ & Variable Definition & $\begin{array}{l}\text { Source of } \\
\text { data }\end{array}$ \\
\hline \multicolumn{3}{|c|}{ Explanatory variables } \\
\hline Gla & Gross leasable area (sq ft) & DMM \\
\hline gla_change & Percentage change of GLA between the first and last observations & DMM \\
\hline number_stores & Number of stores & DMM \\
\hline store_change & Percentage change of number of stores between the first and last observations & DMM \\
\hline year_opened & Year the shopping center was opened & DMM \\
\hline $\begin{array}{l}\text { store_size } \\
(1,000 \text { sq ft) }\end{array}$ & GLA divided by number of stores then divided by 1,000 & DMM \\
\hline enclosed & Indicator variable: 1 if the shopping center is enclosed, 0 if the shopping center is open & DMM \\
\hline WATS & $\begin{array}{l}\text { Weighted average trade area income per sq ft, a proxy for revenue generated per sq ft. } \\
\text { Log of total population-weighted median household income multiplied by weighted } \\
\text { average market share within a trade area and then divided by GLA. } \\
\text { Latitudes and longitudes for all the shopping centers are hand-collected by using the } \\
\text { geographic information system (GIS). Haversine formula is used to estimate the } \\
\text { distance between the shopping center and surrounding tracts within its trade area. } \\
\text { Median household income is from the US Census. }\end{array}$ & $\begin{array}{l}\text { DMM, US } \\
\text { Census, GIS }\end{array}$ \\
\hline type_large & $\begin{array}{l}\text { Indicator variable: } 1 \text { for regional (GLA from } 400,000 \text { to } 800,000 \text { sq } \mathrm{ft} \text { and number of } \\
\text { stores from } 40 \text { to } 80 \text { ) and super regional shopping centers (GLA greater than } 800,000 \\
\text { sq } \mathrm{ft} \text { and number of stores greater than } 80 \text { ), } 0 \text { for community center (GLA from } \\
200,000 \text { to } 400,000 \text { sq } \mathrm{ft} \text {; number of stores from } 15 \text { to } 40 \text { ) and power center (GLA less } \\
\text { than } 400,000 \text { and number of stores less than } 15 \text { or GLA from } 400,000 \text { to } 600,000 \text { and } \\
\text { number of stores from } 15 \text { to } 40 \text { ) }\end{array}$ & DMM \\
\hline compet_ttl & $\begin{array}{l}\text { Total number of competitors within the trade area. } \\
\text { Latitudes and longitudes for all the shopping centers are hand-collected by using the } \\
\text { geographic information system (GIS). Haversine formula is used to calculate the } \\
\text { distances between shopping centers to surrounding census tracts and shopping centers } \\
\text { to its competitors. }\end{array}$ & DMM, GIS \\
\hline compet_share & $\begin{array}{l}\text { Weighted average market share of the competitors within } 5 \text { miles. } \\
\text { Latitudes and longitudes for all the shopping centers are hand-collected by using the } \\
\text { geographic information system (GIS). Haversine formula is used to calculate the } \\
\text { distances between shopping centers to surrounding census tracts and shopping centers } \\
\text { to its competitors. }\end{array}$ & $\begin{array}{l}\text { DMM, US } \\
\text { Census, GIS }\end{array}$ \\
\hline growth5 & $\begin{array}{l}\text { 5-year average of annualized Case-Shiller growth rates around the mid-year of the } \\
\text { observation period }\end{array}$ & S\&P \\
\hline stdev5 & $\begin{array}{l}\text { 5-year average of annualized Case-Shiller standard deviations around the mid-year of } \\
\text { the observation period }\end{array}$ & S\&P \\
\hline
\end{tabular}

Renovation variables

\begin{tabular}{|c|c|c|}
\hline gla_exp & Dummy variable: 1 if GLA increased by $10 \%$, or more 0 otherwise & DMM \\
\hline gla_con & Dummy variable: 1 if GLA decreased by $10 \%$ or more, 0 otherwise & DMM \\
\hline store_exp & Dummy variable: 1 if number of stores increased by $10 \%$ or more, 0 otherwise & DMM \\
\hline store_con & Dummy variable: 1 if number of stores decreased by $10 \%$ or more, 0 otherwise & DMM \\
\hline gla_reno & $\begin{array}{l}\text { Categorical variable: }-1 \text { if GLA decreased by } 10 \% \text { or more and }+1 \text { if GLA increased } \\
\text { by } 10 \% \text { or more, } 0 \text { otherwise }\end{array}$ & DMM \\
\hline store_reno & $\begin{array}{l}\text { Categorical variable: }-1 \text { if number of stores decreased by } 10 \% \text { or more and }+1 \text { if } \\
\text { number of stores increased by } 10 \% \text { or more, } 0 \text { otherwise }\end{array}$ & DMM \\
\hline
\end{tabular}


Table 2: Summary Statistics

The summary statistics are based on a pooled sample of 1995-2000 and 2000-2005. Variables are computed from the DMM 1995, 2000, 2002 and 2005. Panel A includes continuous variables. Panel B presents dummy and MSA-level variables. HH-income is the average household income for census tracts around our sample shopping centers according to the US Census 2000. Growth5 and Stdeb 5 is 5-year Case Shiller growth rate and standard deviation around the mid-year of our observations. Panel C to E compare sub-samples by type, GLA renovation and store renovation. Panel F provide t-statistics and Wilcoxon statistics based on the comparison between each type of renovation and no change. $t$-tests and Wilcoxon tests are used to test the differences in sample mean and median, respectively. Chi-square tests the independence of two samples. *Significant at $10 \%$. **Significant at 5\%. ***Significant at $1 \%$.

\begin{tabular}{lllllll}
\hline Variable & Mean & Median & $\begin{array}{l}\text { Lower } \\
\text { Quartile }\end{array}$ & $\begin{array}{l}\text { Upper } \\
\text { Quartile }\end{array}$ & Std Dev & N \\
\hline \multicolumn{1}{l}{ Panel A: Continuous variables } & & & & & \\
\hline GLA (sq ft) & 612,115 & 456,337 & 310,000 & 875,604 & 379,927 & 599 \\
GLA_change (\%) & 0.94 & 0 & -0.19 & 0.57 & 18.05 & 599 \\
number_stores & 75.61 & 56 & 30 & 118 & 56.29 & 599 \\
store_change (\%) & -0.97 & 0 & -1.88 & 0 & 24.76 & 598 \\
store_size (1,000 sq ft) & 11.95 & 8.13 & 6.30 & 12.11 & 12.85 & 599 \\
year_opened & 1978.15 & 1979 & 1967 & 1990 & 13.64 & 599 \\
WATS (absolute) & 1.84 & 1.46 & 0.77 & 2.47 & 1.68 & 599 \\
WATS (log) & 0.35 & 0.38 & -0.26 & 0.9 & 0.71 & 599 \\
compet_ttl & 11.55 & 9 & 3 & 19 & 9.05 & 599 \\
compet_share & 0.08 & 0.07 & 0.05 & 0.1 & 0.07 & 599 \\
\hline
\end{tabular}

\begin{tabular}{|c|c|c|c|c|c|c|c|c|c|}
\hline \multicolumn{10}{|c|}{ Panel B: Dummy and MSA-level variables } \\
\hline Variable & $\#$ & $\%$ & & & & & & & \\
\hline enclosed & 273 & $46 \%$ & & & & & & & \\
\hline type_large & 318 & $53 \%$ & & & & & & & \\
\hline gla_exp & 55 & $9 \%$ & & & & & & & \\
\hline gla_con & 57 & $10 \%$ & & & & & & & \\
\hline store_exp & 53 & $9 \%$ & & & & & & & \\
\hline \multirow[t]{2}{*}{ store_con } & 110 & $18 \%$ & & & & & & & \\
\hline & & & $\begin{array}{l}\text { HH- } \\
\text { Income }\end{array}$ & Growth5 & Std5 & gla_exp & gla_con & store_exp & store_con \\
\hline MSA & \# & $\%$ & Mean & Mean & Mean & $\#(\%)$ & $\#(\%)$ & $\#(\%)$ & \# (\%) \\
\hline Portland & 26 & $4 \%$ & $57,206.55$ & $9.78 \%$ & $2.21 \%$ & $5(9.09 \%)$ & $1(1.82 \%)$ & $4(7.27 \%)$ & $6(10.91 \%)$ \\
\hline LasVegas & 35 & $6 \%$ & $50,948.81$ & $3.47 \%$ & $1.46 \%$ & 4 (7.27\%) & 3 (5.45\%) & $4(7.27 \%)$ & $1(1.82 \%)$ \\
\hline Minneapolis & 57 & $10 \%$ & $47,053.99$ & $3.76 \%$ & $1.49 \%$ & $6(10.91 \%)$ & 9 (16.36\%) & 3 (5.45\%) & 21 (38.18\%) \\
\hline Charlotte & 48 & $8 \%$ & $52,897.72$ & $6.63 \%$ & $1.33 \%$ & $6(10.91 \%)$ & 5 (9.09\%) & 3 (5.45\%) & 7 (12.73\%) \\
\hline Cleveland & 57 & $10 \%$ & $46,528.88$ & $12.77 \%$ & $2.25 \%$ & 5 (9.09\%) & 9 (16.36\%) & $6(10.91 \%)$ & $10(18.18 \%)$ \\
\hline Boston & 83 & $14 \%$ & $54,647.51$ & $8.37 \%$ & $1.62 \%$ & 8 (14.55\%) & 7 (12.73\%) & 8 (14.55\%) & 21 (38.18\%) \\
\hline Denver & 56 & $9 \%$ & $49,270.20$ & $7.30 \%$ & $1.56 \%$ & 2 (3.64\%) & $4(7.27 \%)$ & 4 (7.27\%) & 15 (27.27\%) \\
\hline SanDiego & 56 & $9 \%$ & $52,889.73$ & $13.77 \%$ & $2.22 \%$ & 4 (7.27\%) & $1(1.82 \%)$ & $6(10.91 \%)$ & 5 (9.09\%) \\
\hline SanJose & 73 & $12 \%$ & $65,571.23$ & $12.72 \%$ & $2.70 \%$ & 2 (3.64\%) & 8 (14.55\%) & 2 (3.64\%) & $16(29.09 \%)$ \\
\hline Seattle & 47 & $8 \%$ & $53,699.98$ & $8.75 \%$ & $1.58 \%$ & 7 (12.73\%) & 8 (14.55\%) & $9(16.36 \%)$ & 8 (14.55\%) \\
\hline Tampa & 61 & $10 \%$ & $40,829.78$ & $10.88 \%$ & $1.42 \%$ & $6(10.91 \%)$ & 3 (5.45\%) & 4 (7.27\%) & 7 (12.73\%) \\
\hline
\end{tabular}


Table 2 (continued): Summary Statistics

\begin{tabular}{|c|c|c|c|c|c|c|c|c|}
\hline \multicolumn{9}{|c|}{ Panel C: Difference in means and median for large and small shopping centers } \\
\hline & \multicolumn{3}{|c|}{$\begin{array}{l}\text { Small shopping } \\
\text { centers }(\mathrm{N}=281)\end{array}$} & \multicolumn{3}{|c|}{$\begin{array}{l}\text { Large shopping centers } \\
(\mathrm{N}=318)\end{array}$} & \multirow{2}{*}{\begin{tabular}{|l|} 
t-test \\
$t-$ \\
\end{tabular}} & \multirow{2}{*}{$\begin{array}{l}\text { Wilcoxon test } \\
Z\end{array}$} \\
\hline Variable & Mean & Median & Std & Mean & Median & Std & & \\
\hline GLA (sq ft) & 346,075 & 310,000 & 127,600 & 847,200 & 841,000 & 373,812 & $-22.47 * * *$ & $-18.05 * * *$ \\
\hline GLA_change (\%) & 1.26 & 0 & 18.49 & 0.65 & 0 & 17.67 & 0.41 & -0.72 \\
\hline number_stores & 32.83 & 30 & 19.62 & 113.42 & 114.5 & 50.82 & $-26.16 * * *$ & $-19.83 * * *$ \\
\hline store_change (\%) & 2.02 & 0 & 29.06 & -3.62 & 0 & 19.88 & $2.74 * *$ & $3.53 * * *$ \\
\hline store_size $(1,000 \mathrm{sq} \mathrm{ft})$ & 16.71 & 11.24 & 17.42 & 7.74 & 7.28 & 2.37 & $8.56 * * *$ & $8.76 * * *$ \\
\hline year_opened & 1982.41 & 1987 & 12.98 & 1974.38 & 1974 & 13.12 & $7.52 * * *$ & $7.40 * * *$ \\
\hline WATS (absolute) & 0.95 & 0.79 & 0.61 & 2.63 & 2.27 & 1.91 & $-22.85 * * *$ & $-17.20 * * *$ \\
\hline compet_ttl & 4.38 & 3 & 3.71 & 17.89 & 18 & 7.51 & $-28.41^{* * *}$ & $-18.52 * * *$ \\
\hline \multirow[t]{2}{*}{ compet_share } & 0.09 & 0.08 & 0.09 & 0.08 & 0.07 & 0.06 & $2.32 * *$ & $2.54 * *$ \\
\hline & \# & $\%$ & & \# & $\%$ & & Chi-square & \\
\hline enclosed & 46 & $16.37 \%$ & & 227 & $71.38 \%$ & & $* * *$ & \\
\hline large & 0 & $0.00 \%$ & & 318 & $100.00 \%$ & & $* * *$ & \\
\hline gla_exp & 15 & $5.34 \%$ & & 40 & $12.58 \%$ & & $* * *$ & \\
\hline gla_con & 15 & $5.34 \%$ & & 42 & $13.21 \%$ & & *** & \\
\hline store_exp & 24 & $8.54 \%$ & & 29 & $9.12 \%$ & & & \\
\hline store_con & 29 & $10.32 \%$ & & 81 & $25.47 \%$ & & $* * *$ & \\
\hline
\end{tabular}

Panel D: Difference in means and median for GLA expansion and contraction

\begin{tabular}{|c|c|c|c|c|c|c|c|c|}
\hline & \multicolumn{3}{|c|}{ GLA expansion $(\mathrm{N}=55)$} & \multicolumn{3}{|c|}{ GLA contraction $(\mathrm{N}=57)$} & \multirow{2}{*}{\begin{tabular}{|l|} 
t-test \\
$t-$
\end{tabular}} & \multirow{2}{*}{$\begin{array}{l}\text { Wilcoxon test } \\
Z Z\end{array}$} \\
\hline Variable & Mean & Median & Std & Mean & Median & Std & & \\
\hline GLA (sq ft) & 606,710 & 500,000 & 314,041 & 763,625 & 670,000 & 404,751 & $-2.3 * *$ & $-1.93 *$ \\
\hline GLA_change (\%) & 33.93 & 17.83 & 40.44 & -23.3 & -20.16 & 12.43 & $10.05^{* * *}$ & $9.12 * * *$ \\
\hline number_stores & 90 & 80 & 50.45 & 87.12 & 85 & 47.32 & 0.31 & 0.25 \\
\hline store_change (\%) & 11.14 & 0 & 49.47 & -9.13 & 0 & 23.76 & $2.75^{* *}$ & $2.46^{* *}$ \\
\hline store_size $(1,000 \mathrm{sq} \mathrm{ft})$ & 9.36 & 6.60 & 12.01 & 10.29 & 8.91 & 7.50 & -0.49 & $-3.35 * * *$ \\
\hline year_opened & 1977.67 & 1978 & 14.75 & 1973.77 & 1972 & 15.97 & 1.34 & 1.46 \\
\hline WATS (absolute) & 2.56 & 2.11 & 2.58 & 1.77 & 1.63 & 1.14 & $2.79 * *$ & $2.27 * *$ \\
\hline compet_ttl & 14.09 & 13 & 8.73 & 15.42 & 16 & 8.64 & -0.81 & -0.91 \\
\hline \multirow[t]{2}{*}{ compet_share } & 0.08 & 0.07 & 0.06 & 0.08 & 0.06 & 0.07 & 0.00 & 0.13 \\
\hline & $\#$ & As a $\%$ & & $\#$ & As a $\%$ & & Chi-square & \\
\hline enclosed & 32 & $58.18 \%$ & & 31 & $54.39 \%$ & & & \\
\hline large & 40 & $72.73 \%$ & & 42 & $73.68 \%$ & & & \\
\hline store_exp & 18 & $32.73 \%$ & & 5 & $8.77 \%$ & & $* * *$ & \\
\hline store_con & 15 & $27.27 \%$ & & 19 & $33.33 \%$ & & & \\
\hline
\end{tabular}

\begin{tabular}{|c|c|c|c|c|c|c|c|c|}
\hline \multicolumn{9}{|c|}{ Panel E: Difference in means and median for Store expansion and contraction } \\
\hline & \multicolumn{3}{|c|}{ Store expansion $(\mathrm{N}=53)$} & \multicolumn{3}{|c|}{ Store contraction $(\mathrm{N}=110)$} & \multirow{2}{*}{\begin{tabular}{|l|} 
t-test \\
$t-$
\end{tabular}} & \multirow{2}{*}{$\begin{array}{l}\text { Wilcoxon test } \\
z\end{array}$} \\
\hline Variable & Mean & Median & Std & Mean & Median & Std & & \\
\hline GLA (sq ft) & 602,732 & 470,000 & 375,452 & 700,344 & 612,500 & 400,399 & -1.52 & $-1.84 * *$ \\
\hline GLA_change (\%) & 14.51 & 3.59 & 33.52 & -1.99 & 0 & 13.15 & $3.46 * * *$ & $3.61^{* * *}$ \\
\hline number_stores & 67.04 & 67 & 48.37 & 96.75 & 86 & 64.67 & $-3.28 * *$ & $-2.89 * * *$ \\
\hline store_change (\%) & 44.86 & 30.43 & 52.45 & -27.41 & -21.88 & 17.15 & $9.78^{* * *}$ & $10.31 * * *$ \\
\hline store_size $(1,000 \mathrm{sq} \mathrm{ft})$ & 17.30 & 9.86 & 20.45 & 8.71 & 7.13 & 6.30 & $2.99 * * *$ & $2.73 * * *$ \\
\hline year_opened & 1981.62 & 1989 & 14.19 & 1972.76 & 1972 & 13.14 & $3.82 * * *$ & $4.00 * * *$ \\
\hline WATS (absolute) & 2.17 & 1.66 & 2.54 & 1.92 & 1.77 & 1.21 & 0.67 & 0.25 \\
\hline compet_ttl & 12.79 & 13 & 9 & 14.75 & 15 & 9.25 & -0.53 & -0.68 \\
\hline \multirow[t]{2}{*}{ compet_share } & 0.08 & 0.07 & 0.09 & 0.09 & 0.07 & 0.09 & -1.29 & -1.46 \\
\hline & \# & $\%$ & & \# & $\%$ & & Chi-square & \\
\hline enclosed & 22 & $41.51 \%$ & & 69 & $62.73 \%$ & & *** & \\
\hline large & 29 & $54.72 \%$ & & 81 & $73.64 \%$ & & ** & \\
\hline gla_exp & 18 & $33.96 \%$ & & 15 & $13.64 \%$ & & *** & \\
\hline gla_con & 5 & $9.43 \%$ & & 19 & $17.27 \%$ & & & \\
\hline
\end{tabular}


Table 2 (continued): Summary Statistics

Panel F: Difference in means and median for renovation and no change

\begin{tabular}{|c|c|c|c|c|c|c|c|c|c|c|c|c|}
\hline \multirow{11}{*}{$\begin{array}{l}\text { Variable } \\
\text { GLA (sq ft) } \\
\text { GLA_change } \\
\text { number_stores } \\
\text { store_change } \\
\text { store_size } \\
\text { year_opened } \\
\text { WATS } \\
\text { compet_ttl } \\
\text { compet_share } \\
\end{array}$} & \multicolumn{3}{|c|}{$\begin{array}{c}\text { GLA-exp }=1(\mathrm{~N}=55) \\
\text { Versus } \\
\text { GLA-exp }=0(\mathrm{~N}=544)\end{array}$} & \multicolumn{3}{|c|}{$\begin{array}{c}\text { GLA-con }=1(\mathrm{~N}=57) \\
\text { versus } \\
\text { GLA-con }=0(\mathrm{~N}=542)\end{array}$} & \multicolumn{3}{|c|}{$\begin{array}{l}\text { store-exp }=1(\mathrm{~N}=53) \\
\text { versus } \\
\text { store-exp }=0(\mathrm{~N}=546)\end{array}$} & \multicolumn{3}{|c|}{$\begin{array}{c}\text { store-con }=1(\mathrm{~N}=110) \\
\text { versus } \\
\text { store-con }=0(\mathrm{~N}=489)\end{array}$} \\
\hline & t-test & \multicolumn{2}{|l|}{ Wilcoxon test } & \multirow{2}{*}{$\begin{array}{l}\text { t-test } \\
99 * * *\end{array}$} & \multicolumn{2}{|l|}{ Wilcoxon test } & \multirow{2}{*}{$\begin{array}{c}\text { t-test } \\
-0.19\end{array}$} & \multicolumn{2}{|c|}{ Wilcoxon test } & \multirow{2}{*}{$\frac{\text { t-test }}{2.59^{* *}}$} & \multicolumn{2}{|l|}{ Wilcoxon test } \\
\hline & -0.13 & 0.55 & & & $3.42 * * *$ & & & -0.35 & & & $3.10 * * *$ & \\
\hline & $6.65 * * *$ & $12.78 * * *$ & & $-14.93 * * *$ & $-12.99 * * *$ & & $3.2^{* * *}$ & $4.86^{* * *}$ & & $-2.36^{* *}$ & -0.64 & \\
\hline & $2.19 * *$ & $2.63^{* * *}$ & & $1.89 *$ & $2.47 * * *$ & & -1.33 & -1.21 & & $3.91 * * *$ & $4.54 * * *$ & \\
\hline & $1.98^{*}$ & $2.11^{* *}$ & & $-2.71 * * *$ & $-2.27 * *$ & & $6.96 * * *$ & $13.29 * * *$ & & $-16.79 * * *$ & $-18.05^{* * *}$ & \\
\hline & $-1.67 *$ & $-3.87 * * *$ & & -1.6 & 0.94 & & $2.06 * *$ & $1.67^{*}$ & & $-4.58 * * *$ & $-3.58 * * *$ & \\
\hline & -0.25 & -0.03 & & $-2.21 * *$ & $-2.29 * *$ & & $1.87 *$ & $2.27 * *$ & & $-4.73 * * *$ & $-4.69 * * *$ & \\
\hline & $4.15^{* * *}$ & $3.78 * * *$ & & -0.19 & 0.23 & & $1.82 *$ & $1.71^{*}$ & & 1.37 & 1.46 & \\
\hline & $2.26 * *$ & $2.41 * *$ & & $3.54 * * *$ & $3.58 * * *$ & & 1.05 & 0.87 & & $4.05^{* * *}$ & $4.09 * * *$ & \\
\hline & -1.12 & -1.44 & & -1.08 & -1.15 & & -0.38 & -1.39 & & 0.48 & -1.22 & \\
\hline & $\begin{array}{l}\text { GLA-exp=1 } \\
\#(\%)\end{array}$ & $\begin{array}{l}\text { GLA-exp=0 } \\
\#(\%)\end{array}$ & $\begin{array}{l}\text { Chi- } \\
\text { Sq }\end{array}$ & $\begin{array}{l}\text { GLA-con=1 } \\
\#(\%)\end{array}$ & $\begin{array}{l}\text { GLA-con=0 } \\
\#(\%)\end{array}$ & $\begin{array}{l}\text { Chi- } \\
\text { sq }\end{array}$ & $\begin{array}{l}\text { store-exp=1 } \\
\#(\%)\end{array}$ & $\begin{array}{l}\text { store-exp=0 } \\
\#(\%)\end{array}$ & $\begin{array}{l}\text { Chi- } \\
\text { sq }\end{array}$ & $\begin{array}{l}\text { store-con=1 } \\
\#(\%)\end{array}$ & $\begin{array}{l}\text { store-con=0 } \\
\#(\%)\end{array}$ & $\begin{array}{l}\text { Chi- } \\
\text { sq }\end{array}$ \\
\hline enclosed & $32(58.18 \%)$ & 241 (44.30\%) & $* *$ & 31 (54.39\%) & 242 (44.65\%) & & $22(41.51 \%)$ & 251 (45.97\%) & & $69(62.73 \%)$ & $204(41.72 \%)$ & $* * *$ \\
\hline large & $40(72.73 \%)$ & $278(51.10 \%)$ & $* * *$ & 42 (73.68\%) & 276 (50.92\%) & $* * *$ & $29(54.72 \%)$ & 289 (52.93\%) & & 81 (73.64\%) & 237 (48.47\%) & $* * *$ \\
\hline gla_exp & 55 (100.00\%) & $0(0.00 \%)$ & N.A. & $0(0.00 \%)$ & 55 (10.15\%) & N.A. & $18(33.96 \%)$ & 37 (6.78\%) & $* * *$ & 15 (13.64\%) & 40 (8.18\%) & * \\
\hline gla_con & $0(0.00 \%)$ & $57(10.48 \%)$ & N.A. & 57 (100.00\%) & $0(0.00 \%)$ & N.A. & 5 (9.43\%) & 52 (9.52\%) & & 19 (17.27\%) & $38(7.77 \%)$ & $* * *$ \\
\hline store_exp & 18 (32.73\%) & 35 (6.43\%) & $* * *$ & $5(8.77 \%)$ & 48 (8.86\%) & & 53 (100.00\%) & $0(0.00 \%)$ & N.A. & $0(0.00 \%)$ & 53 (10.84\%) & N.A. \\
\hline store con & $15(27.27 \%)$ & 95 (17.46\%) & * & 19 (33.33\%) & $91(16.79 \%)$ & $* * *$ & $0(0.00 \%)$ & 110 (20.15\%) & N.A. & 110 (100.00\%) & $0(0.00 \%)$ & N.A. \\
\hline
\end{tabular}


Table 3: Ordered Logistic Regression - full sample

Ordered logistic regressions are based on a pooled sample of 1995-2000 and 2000-2005. Variables are computed from the DMM 1995, 2000, 2002 and 2005. See Table 1 for variable definitions. Continuous variables are normalized with zero mean and unit standard deviation. gla_reno equals - 1 if GLA decreased by $10 \%$ or more and +1 if GLA increase by $10 \%$ or more during the observation period and 0 otherwise. store_reno equals -1 if number of stores decreased by $10 \%$ or more and +1 if number of stores increase by $10 \%$ or more during the observation period and 0 otherwise. Total effect of large shopping centers equals the sum of all standardized coefficients associated with large shopping centers multiplied by the median value of the non-standardized variable. Net effect tests whether the sum of a standardized coefficient and its large-shopping center dummy equals zero. $p$-value is reported below coefficient estimates. Robust variance estimator is used to adjust data clustering. Fixed effect in MSA level is used. MSA dummy coefficients are not reported in the table. /cut1 is the estimated cutpoint on the latent variable used to differentiate contraction from no change and expansion when values of the predictor variables are evaluated at zero. /cut2 is the estimated cutpoint on the latent variable used to differentiate contraction and no change from expansion when values of the predictor variables are evaluated at zero. $p$-values are reported in parentheses.* Significant at 10\%; ** Significant at 5\%; *** Significant at $1 \%$.

\begin{tabular}{|c|c|c|c|c|c|c|}
\hline & \multicolumn{2}{|c|}{ (1) } & \multicolumn{2}{|c|}{ (2) } & \multicolumn{2}{|c|}{ (3) } \\
\hline & gla_reno & store_reno & gla_reno & store_reno & gla_reno & store_reno \\
\hline enclosed & $\begin{array}{l}-0.08 \\
(0.79)\end{array}$ & $\begin{array}{l}-0.42 \\
(0.12)\end{array}$ & $\begin{array}{l}-0.01 \\
(0.97)\end{array}$ & $\begin{array}{l}-0.44 \\
(0.11)\end{array}$ & $\begin{array}{l}-0.13 \\
(0.65)\end{array}$ & $\begin{array}{l}-0.50^{*} \\
(0.07)\end{array}$ \\
\hline type_large & $\begin{array}{l}-2.20^{* * *} \\
(0.00)\end{array}$ & $\begin{array}{l}-0.71 \\
(0.12)\end{array}$ & $\begin{array}{l}-1.90^{* * *} \\
(0.00)\end{array}$ & $\begin{array}{l}-0.68 \\
(0.22)\end{array}$ & $\begin{array}{l}-2.27 * * * \\
(0.00)\end{array}$ & $\begin{array}{l}-0.80^{*} \\
(0.08)\end{array}$ \\
\hline WATS & $\begin{array}{l}0.65^{* * *} \\
(0.01)\end{array}$ & $\begin{array}{l}0.22 \\
(0.26)\end{array}$ & $\begin{array}{l}0.69 * * * \\
(0.00)\end{array}$ & $\begin{array}{l}0.24 \\
(0.23)\end{array}$ & $\begin{array}{l}0.67 * * * \\
(0.01)\end{array}$ & $\begin{array}{l}0.23 \\
(0.24)\end{array}$ \\
\hline WATS*large & $\begin{array}{l}0.15 \\
(0.61)\end{array}$ & $\begin{array}{l}0.62 * * * \\
(0.01)\end{array}$ & $\begin{array}{l}0.15 \\
(0.61)\end{array}$ & $\begin{array}{l}0.59 * * \\
(0.01)\end{array}$ & $\begin{array}{l}0.16 \\
(0.58)\end{array}$ & $\begin{array}{l}0.65^{* * *} \\
(0.01)\end{array}$ \\
\hline store_size & $\begin{array}{l}-0.02 \\
(0.82)\end{array}$ & $\begin{array}{l}0.26^{* *} \\
(0.01)\end{array}$ & $\begin{array}{l}0.00 \\
(0.97)\end{array}$ & $\begin{array}{l}0.27 * * * \\
(0.01)\end{array}$ & $\begin{array}{l}-0.02 \\
(0.81)\end{array}$ & $\begin{array}{l}0.27 * * \\
(0.01)\end{array}$ \\
\hline store_size*large & $\begin{array}{l}-3.76^{* * *} \\
(0.00)\end{array}$ & $\begin{array}{l}0.89 \\
(0.36)\end{array}$ & $\begin{array}{l}-3.69 * * * \\
(0.00)\end{array}$ & $\begin{array}{l}0.83 \\
(0.40)\end{array}$ & $\begin{array}{l}-3.92 * * * \\
(0.00)\end{array}$ & $\begin{array}{l}0.70 \\
(0.48)\end{array}$ \\
\hline $\begin{array}{l}\text { compet_ttl } \\
\text { compet_ttl*large }\end{array}$ & & & $\begin{array}{l}-0.27 \\
(0.47) \\
0.10 \\
(0.81)\end{array}$ & $\begin{array}{l}-0.11 \\
(0.80) \\
0.17 \\
(0.70)\end{array}$ & & \\
\hline compet_share & & & & & $\begin{array}{l}0.02 \\
(0.80)\end{array}$ & $\begin{array}{l}-0.05 \\
(0.73)\end{array}$ \\
\hline compet_share*large & & & & & $\begin{array}{l}-0.35 \\
(0.19)\end{array}$ & $\begin{array}{l}-0.33 \\
(0.11)\end{array}$ \\
\hline /cut 1 & $\begin{array}{l}-3.32 * * * \\
(0.00)\end{array}$ & $\begin{array}{l}-2.59 * * * \\
(0.00)\end{array}$ & $\begin{array}{l}-3.07 * * * \\
(0.00)\end{array}$ & $\begin{array}{l}-2.52 * * * \\
(0.00)\end{array}$ & $\begin{array}{l}-3.39 * * * \\
(0.00)\end{array}$ & $\begin{array}{l}-2.69 * * * \\
(0.00)\end{array}$ \\
\hline /cut 2 & $\begin{array}{l}1.67^{* * *} \\
(0.00) \\
\end{array}$ & $\begin{array}{l}1.67 * * * \\
(0.00) \\
\end{array}$ & $\begin{array}{l}1.93^{* * *} \\
(0.00)\end{array}$ & $\begin{array}{l}1.74 * * * \\
(0.00)\end{array}$ & $\begin{array}{l}1.63 * * * \\
(0.00) \\
\end{array}$ & $\begin{array}{l}1.60 * * * \\
(0.00) \\
\end{array}$ \\
\hline Net effect & & & & & & \\
\hline WATS & $\begin{array}{l}0.80^{* * * *} \\
(0.00)\end{array}$ & $\begin{array}{l}0.84 * * * \\
(0.00)\end{array}$ & $\begin{array}{l}0.84 * * * \\
(0.00)\end{array}$ & $\begin{array}{l}0.83^{* * *} \\
(0.00)\end{array}$ & $\begin{array}{l}0.83^{* * *} \\
(0.00)\end{array}$ & $\begin{array}{l}0.88 * * * \\
(0.00)\end{array}$ \\
\hline store_size & $\begin{array}{l}-3.78^{* * *} \\
(0.00)\end{array}$ & $\begin{array}{l}1.15 \\
(0.23)\end{array}$ & $\begin{array}{l}-3.69 * * * \\
(0.00)\end{array}$ & $\begin{array}{l}1.10 \\
(0.24)\end{array}$ & $\begin{array}{l}-3.94 * * * \\
(0.00)\end{array}$ & $\begin{array}{l}0.97 \\
(0.31)\end{array}$ \\
\hline compet_ttl & & & $\begin{array}{l}-0.17 \\
(0.44)\end{array}$ & $\begin{array}{l}0.06 \\
(0.99)\end{array}$ & & \\
\hline compet_share & & & & & $\begin{array}{l}-0.33 \\
(0.21)\end{array}$ & $\begin{array}{l}-0.38^{* *} \\
(0.04)\end{array}$ \\
\hline Prob>chi2 & $0.00 * * *$ & $0.00 * * *$ & $0.00 * * *$ & $0.00 * * *$ & $0.00 * * *$ & $0.00 * * *$ \\
\hline Pseudo R2 & 0.075 & 0.079 & 0.077 & 0.079 & 0.079 & 0.085 \\
\hline Obs & 599 & 599 & 599 & 599 & 599 & 599 \\
\hline
\end{tabular}


Table 4: Ordered Logistic Regression by size category

Ordered logistic regressions are based on a pooled sample of 1995-2000 and 2000-2005. Variables are computed from the DMM 1995, 2000, 2002 and 2005. See Table 1 for variable definitions. Continuous variables are normalized with zero mean and unit standard deviation. Panel A includes only large shopping centers (regional and super regional) and Panel B includes only small shopping centers (community and power centers). Gla_ reno equals -1 if GLA decreased by $10 \%$ or more and +1 if GLA increase by $10 \%$ or more during the observation period and 0 otherwise. Store_reno equals -1 if number of stores decreased by $10 \%$ or more and +1 if number of stores increase by $10 \%$ or more during the observation period and 0 otherwise. $p$-value is reported below coefficient estimates. Robust variance estimator is used to adjust data clustering. Fixed effect in MSA level is used. MSA dummy coefficients are not reported in the table. /cut1 is the estimated cutpoint on the latent variable used to differentiate contraction from no change and expansion when values of the predictor variables are evaluated at zero. /cut2 is the estimated cutpoint on the latent variable used to differentiate contraction and no change from expansion when values of the predictor variables are evaluated at zero. $p$-values are reported in parentheses. *Significant at $10 \%$; **Significant at $5 \%$; ***Significant at $1 \%$.

\begin{tabular}{|c|c|c|c|c|c|c|}
\hline \multicolumn{7}{|c|}{ Panel A - Large shopping centers } \\
\hline & \multicolumn{2}{|c|}{ (1) } & \multicolumn{2}{|c|}{ (2) } & \multicolumn{2}{|c|}{ (3) } \\
\hline & gla_reno & store_reno & gla_reno & store_reno & gla_reno & store_reno \\
\hline enclosed & $\begin{array}{l}-0.35 \\
(0.28)\end{array}$ & $\begin{array}{l}-0.49 \\
(0.12)\end{array}$ & $\begin{array}{l}-0.27 \\
(0.43)\end{array}$ & $\begin{array}{l}-0.59 * \\
(0.07)\end{array}$ & $\begin{array}{l}-0.43 \\
(0.19)\end{array}$ & $\begin{array}{l}-0.62 * \\
(0.05)\end{array}$ \\
\hline WATS & $\begin{array}{l}0.78^{* * *} \\
(0.00)\end{array}$ & $\begin{array}{l}0.94 * * * \\
(0.00)\end{array}$ & $\begin{array}{l}0.80 * * * \\
(0.00)\end{array}$ & $\begin{array}{l}0.93^{* * *} \\
(0.00)\end{array}$ & $\begin{array}{l}0.82^{* * *} \\
(0.00)\end{array}$ & $\begin{array}{l}1.01^{* * * *} \\
(0.00)\end{array}$ \\
\hline store_size & $\begin{array}{l}-2.97 * * * \\
(0.00)\end{array}$ & $\begin{array}{l}1.62 * \\
(0.07)\end{array}$ & $\begin{array}{l}-2.87 * * * \\
(0.00)\end{array}$ & $\begin{array}{l}1.49 \\
(0.10)\end{array}$ & $\begin{array}{l}-3.11^{* * *} \\
(0.00)\end{array}$ & $\begin{array}{l}1.44 \\
(0.12)\end{array}$ \\
\hline compet_ttl & & & $\begin{array}{l}-0.16 \\
(0.45)\end{array}$ & $\begin{array}{l}0.2 \\
(0.25)\end{array}$ & & \\
\hline compet_share & & & & & $\begin{array}{l}-0.28 \\
(0.19)\end{array}$ & $\begin{array}{l}-0.39 * * \\
(0.01)\end{array}$ \\
\hline /cut 1 & $\begin{array}{l}-1.23^{* *} \\
(0.02)\end{array}$ & $\begin{array}{l}-2.29 * * * \\
(0.00)\end{array}$ & $\begin{array}{l}-1.27 * * \\
(0.02)\end{array}$ & $\begin{array}{l}-2.24 * * * \\
(0.00)\end{array}$ & $\begin{array}{l}-1.28 * * \\
(0.02)\end{array}$ & $\begin{array}{l}-2.38 * * * \\
(0.00)\end{array}$ \\
\hline /cut 2 & $\begin{array}{l}3.03^{* * *} \\
(0.00) \\
\end{array}$ & $\begin{array}{l}1.55^{* * *} \\
(0.00)\end{array}$ & $\begin{array}{l}3.00^{* * *} \\
(0.00)\end{array}$ & $\begin{array}{l}1.61 * * * \\
(0.00)\end{array}$ & $\begin{array}{l}3.01 * * * \\
(0.00)\end{array}$ & $\begin{array}{l}1.51 * * * \\
(0.01)\end{array}$ \\
\hline Prob>chi2 & $0.00^{* * *}$ & $0.00^{* * *}$ & $0.00^{* * *}$ & $0.00 * * *$ & $0.00^{* * *}$ & $0.00^{* * *}$ \\
\hline Pseudo R2 & 0.0798 & 0.0950 & 0.0813 & 0.0973 & 0.0853 & 0.1064 \\
\hline Obs & 318 & 318 & 318 & 318 & 318 & 318 \\
\hline
\end{tabular}

\begin{tabular}{lll|ll|ll}
\hline \multicolumn{2}{l}{ Panel B - Small shopping centers } \\
\hline & \multicolumn{2}{c}{$(1)$} & \multicolumn{2}{c}{$(2)$} & \multicolumn{2}{c}{$(3)$} \\
\hline & gla_reno & store_reno & gla_reno & store_reno & gla_reno & store_reno \\
\hline enclosed & 0.32 & -0.87 & 0.34 & -0.86 & 0.32 & -0.87 \\
& $(0.52)$ & $(0.13)$ & $(0.54)$ & $(0.14)$ & $(0.52)$ & $(0.13)$ \\
WATS & $0.85^{* *}$ & 0.39 & $0.86^{* *}$ & 0.41 & $0.85^{* *}$ & 0.39 \\
& $(0.04)$ & $(0.18)$ & $(0.04)$ & $(0.17)$ & $(0.04)$ & $(0.18)$ \\
store_size & -0.024 & $0.33^{* * *}$ & -0.014 & $0.33^{* * *}$ & -0.025 & $0.33^{* * *}$ \\
& $(0.89)$ & $(0.00)$ & $(0.93)$ & $(0.00)$ & $(0.89)$ & $(0.00)$ \\
compet_ttl & & & -0.12 & -0.08 & & \\
& & & $(0.87)$ & $(0.88)$ & & \\
compet_share & & & & & 0.01 & -0.02 \\
& & & & & $(0.96)$ & $(0.91)$ \\
/cut 1 & $-4.37^{* * *}$ & $-2.70^{* * *}$ & $-4.25^{* * *}$ & $-2.63^{* * *}$ & $-4.37^{* * *}$ & $-2.71^{* * *}$ \\
& $(0.00)$ & $(0.00)$ & $(0.00)$ & $(0.00)$ & $(0.00)$ & $(0.00)$ \\
/cut 2 & $2.18^{* * *}$ & $2.38^{* * *}$ & $2.30^{*}$ & $2.44^{* * *}$ & $2.18^{* *}$ & $2.37^{* * *}$ \\
& $(0.01)$ & $(0.00)$ & $(0.05)$ & $(0.00)$ & $(0.01)$ & $(0.00)$ \\
\hline Prob>chi2 & 0.10 & $0.00^{* * *}$ & $0.08^{*}$ & $0.00^{* * *}$ & 0.13 & $0.00^{* * *}$ \\
Pseudo R2 & 0.1043 & 0.0828 & 0.1045 & 0.0829 & 0.1042 & 0.0828 \\
Obs & 281 & 281 & 281 & 281 & 281 & 281 \\
\hline
\end{tabular}


Table 5: Multinomial logistic regression - full sample

Multinomial logistic regressions are based on a pooled sample of 1995-2000 and 2000-2005. Variables are computed from the DMM 1995, 2000, 2002 and 2005. See Table 1 for variable definitions. Continuous variables are normalized with zero mean and unit standard deviation. Gla_ reno equals -1 if GLA decreased by $10 \%$ or more and +1 if GLA increase by $10 \%$ or more during the observation period and 0 otherwise. Store_reno equals -1 if number of stores decreased by $10 \%$ or more and +1 if number of stores increase by $10 \%$ or more during the observation period and 0 otherwise. Total effect of large shopping centers equals the sum of all standardized coefficients associated with large shopping centers multiplied by the median value of the non-standardized variable. Net effect tests whether the sum of a standardized coefficient and its large-shopping center dummy equals zero. $p$-value is reported below coefficient estimates. $p$-value is reported below coefficient estimates. Robust variance estimator is used to adjust data clustering. Fixed effect in MSA level is used. MSA dummy coefficients are not reported in the table. $p$-values are reported in parentheses.* Significant at $10 \%$; ** Significant at $5 \%$; *** Significant at $1 \%$.

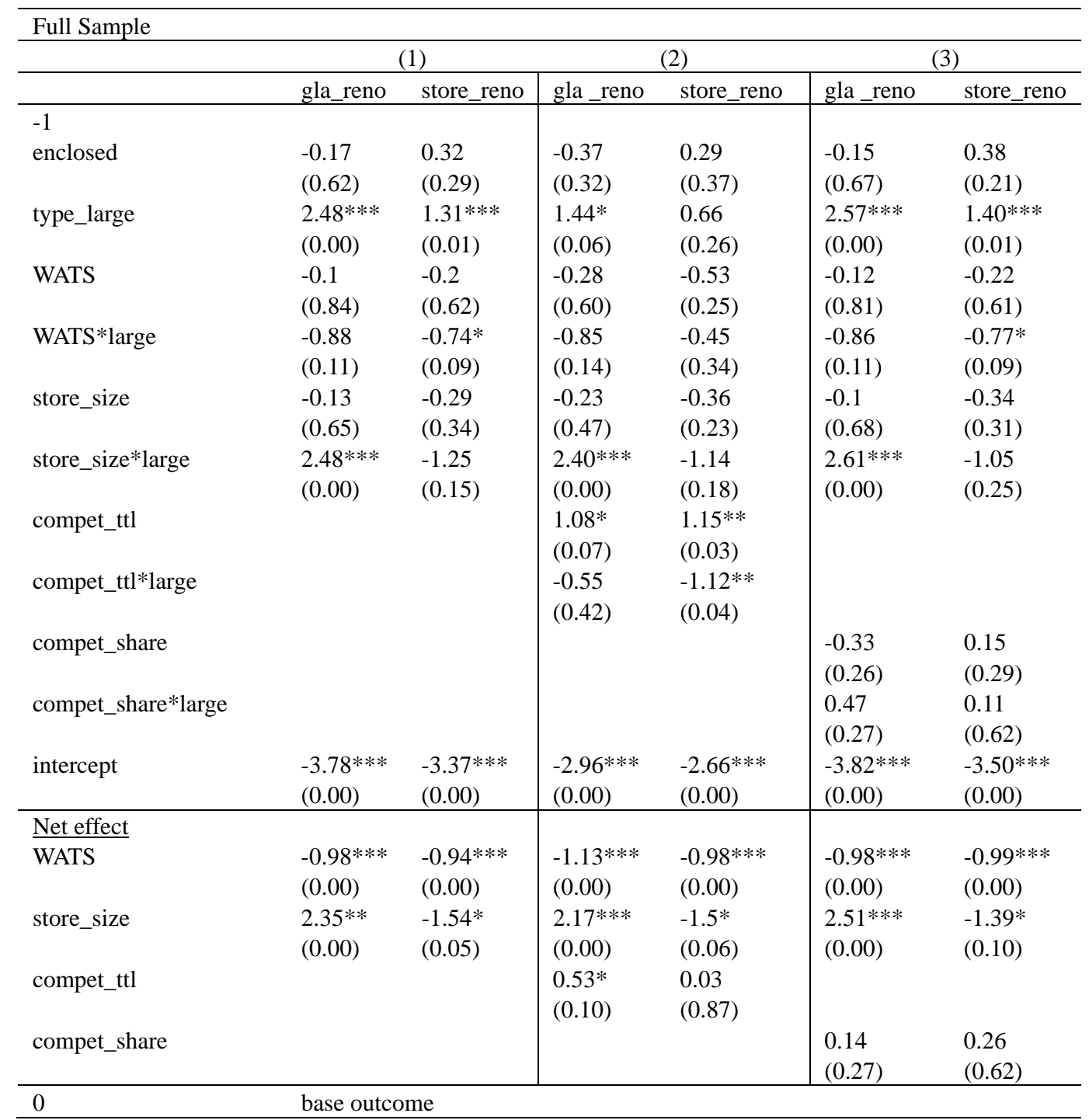


Table 5 (continued): Multinomial logistic regression - full sample

\begin{tabular}{|c|c|c|c|c|c|c|}
\hline & \multicolumn{2}{|c|}{ (1) } & \multicolumn{2}{|c|}{ (2) } & \multicolumn{2}{|c|}{ (3) } \\
\hline & gla_reno & store_reno & gla_reno & store_reno & gla_reno & store_reno \\
\hline enclosed & $\begin{array}{l}-0.3 \\
(0.42)\end{array}$ & $\begin{array}{l}-0.51 \\
(0.23)\end{array}$ & $\begin{array}{l}-0.43 \\
(0.27)\end{array}$ & $\begin{array}{l}-0.61 \\
(0.15)\end{array}$ & $\begin{array}{l}-0.38 \\
(0.32)\end{array}$ & $\begin{array}{l}-0.61 \\
(0.15)\end{array}$ \\
\hline type_large & $\begin{array}{l}-0.76 \\
(0.34)\end{array}$ & $\begin{array}{l}0.33 \\
(0.64)\end{array}$ & $\begin{array}{l}-1.45^{*} \\
(0.09)\end{array}$ & $\begin{array}{l}-0.37 \\
(0.66)\end{array}$ & $\begin{array}{l}-0.76 \\
(0.32)\end{array}$ & $\begin{array}{l}0.24 \\
(0.72)\end{array}$ \\
\hline WATS & $\begin{array}{l}1.34^{* * * *} \\
(0.00)\end{array}$ & $\begin{array}{l}0.37 \\
(0.22)\end{array}$ & $\begin{array}{l}1.29 * * * \\
(0.00)\end{array}$ & $\begin{array}{l}0.26 \\
(0.45)\end{array}$ & $\begin{array}{l}1.33^{* * * *} \\
(0.00)\end{array}$ & $\begin{array}{l}0.38 \\
(0.21)\end{array}$ \\
\hline WATS*large & $\begin{array}{l}-1.05^{* *} \\
(0.02)\end{array}$ & $\begin{array}{l}0.11 \\
(0.75)\end{array}$ & $\begin{array}{l}-1.03^{* *} \\
(0.02)\end{array}$ & $\begin{array}{l}0.19 \\
(0.63)\end{array}$ & $\begin{array}{l}-1.03^{* *} \\
(0.02)\end{array}$ & $\begin{array}{l}0.11 \\
(0.76)\end{array}$ \\
\hline store_size & $\begin{array}{l}-0.11 \\
(0.62)\end{array}$ & $\begin{array}{l}0.33^{* * *} \\
(0.00)\end{array}$ & $\begin{array}{l}-0.21 \\
(0.32)\end{array}$ & $\begin{array}{l}0.26 * * \\
(0.03)\end{array}$ & $\begin{array}{l}-0.11 \\
(0.62)\end{array}$ & $\begin{array}{l}0.33^{* * *} \\
(0.00)\end{array}$ \\
\hline store_size*large & $\begin{array}{l}-2.83^{*} \\
(0.07)\end{array}$ & $\begin{array}{l}0.098 \\
(0.95)\end{array}$ & $\begin{array}{l}-2.94^{*} \\
(0.06)\end{array}$ & $\begin{array}{l}-0.1 \\
(0.95)\end{array}$ & $\begin{array}{l}-2.84^{*} \\
(0.05)\end{array}$ & $\begin{array}{l}-0.12 \\
(0.92)\end{array}$ \\
\hline compet_ttl & & & $\begin{array}{l}0.73 \\
(0.14)\end{array}$ & $\begin{array}{l}0.65 \\
(0.30)\end{array}$ & & \\
\hline compet_ttl*large & & & $\begin{array}{l}-0.49 \\
(0.35)\end{array}$ & $\begin{array}{l}-0.31 \\
(0.64)\end{array}$ & & \\
\hline compet_share & & & & & $\begin{array}{l}-0.03 \\
(0.89)\end{array}$ & $\begin{array}{l}0.07 \\
(0.70)\end{array}$ \\
\hline compet_share*large & & & & & $\begin{array}{l}-0.36 \\
(0.30)\end{array}$ & $\begin{array}{l}-0.54 \\
(0.11)\end{array}$ \\
\hline intercept & $\begin{array}{l}-2.11 * * * \\
(0.00)\end{array}$ & $\begin{array}{l}-2.41 * * * \\
(0.00)\end{array}$ & $\begin{array}{l}-1.44^{*} \\
(0.05)\end{array}$ & $\begin{array}{l}-1.83^{* *} \\
(0.01)\end{array}$ & $\begin{array}{l}-2.04 * * * \\
(0.00)\end{array}$ & $\begin{array}{l}-2.37 * * * \\
(0.00)\end{array}$ \\
\hline Total effect & $\begin{array}{l}-24.17 \\
(0.96)\end{array}$ & $\begin{array}{l}1.17 \\
(0.55)\end{array}$ & $\begin{array}{l}-30.15 \\
(0.48)\end{array}$ & $\begin{array}{l}-3.9 \\
(0.57)\end{array}$ & $\begin{array}{l}-24.27 \\
(0.84)\end{array}$ & $\begin{array}{l}-0.73 \\
(0.56)\end{array}$ \\
\hline Net effect & & & & & & \\
\hline WATS & $\begin{array}{l}0.29 * \\
(0.05)\end{array}$ & $\begin{array}{l}0.48^{*} \\
(0.05)\end{array}$ & $\begin{array}{l}0.26 \\
(0.25)\end{array}$ & $\begin{array}{l}0.45 \\
(0.09 *)\end{array}$ & $\begin{array}{l}0.3 \\
(0.16)\end{array}$ & $\begin{array}{l}0.49 * * \\
(0.04)\end{array}$ \\
\hline store_size & $\begin{array}{l}-2.94 \\
(0.19)\end{array}$ & $\begin{array}{l}0.428 \\
(0.77)\end{array}$ & $\begin{array}{l}-3.15^{* *} \\
(0.04)\end{array}$ & $\begin{array}{l}0.16 \\
(0.91)\end{array}$ & $\begin{array}{l}-2.95^{* *} \\
(0.04)\end{array}$ & $\begin{array}{l}0.21 \\
(0.88)\end{array}$ \\
\hline compet_ttl & & & $\begin{array}{l}0.24 \\
(0.34)\end{array}$ & $\begin{array}{l}0.34 \\
(0.21)\end{array}$ & & \\
\hline compet_share & & & & & $\begin{array}{l}-0.39 \\
(0.30) \\
\end{array}$ & $\begin{array}{l}-0.47 \\
(0.11) \\
\end{array}$ \\
\hline Prob>chi2 & $0.00 * * *$ & $0.00 * * *$ & $0.00 * * *$ & $0.00 * * *$ & $0.00 * * *$ & $0.00 * * *$ \\
\hline Pseudo R2 & 0.1378 & 0.1201 & 0.1473 & 0.1264 & 0.1431 & 0.1270 \\
\hline Obs & 599 & 599 & 599 & 599 & 599 & 599 \\
\hline
\end{tabular}


Table 6: Multinomial logistic by size category

Multinomial logistic regressions are based on a pooled sample of 1995-2000 and 2000-2005. Variables are computed from the DMM 1995, 2000, 2002 and 2005. See Table 1 for variable definitions. Continuous variables are normalized with zero mean and unit standard deviation. Panel A includes only large shopping centers (regional and super regional) and Panel B includes only small shopping centers(community and power centers). Gla_ reno equals -1 if GLA decreased by $10 \%$ or more and +1 if GLA increase by $10 \%$ or more during the observation period and 0 otherwise. Store_reno equals -1 if number of stores decreased by $10 \%$ or more and +1 if number of stores increase by $10 \%$ or more during the observation period and 0 otherwise. $p$-value is reported below coefficient estimates. Robust variance estimator is used to adjust data clustering. Fixed effect in MSA level is used. MSA dummy coefficients are not reported in the table. $p$-values are reported in parentheses. * Significant at $10 \%$; ** Significant at $5 \%$; *** Significant at $1 \%$.

\begin{tabular}{|c|c|c|c|c|c|c|}
\hline \multicolumn{7}{|c|}{ Panel A - Large shopping centers } \\
\hline & \multicolumn{2}{|c|}{ (1) } & \multicolumn{2}{|c|}{ (2) } & \multicolumn{2}{|c|}{ (3) } \\
\hline & gla_reno & store_reno & gla_reno & store_reno & gla_reno & store_reno \\
\hline-1 & & & & & & \\
\hline enclosed & $\begin{array}{l}0.07 \\
(0.89)\end{array}$ & $\begin{array}{l}0.3 \\
(0.42)\end{array}$ & $\begin{array}{l}-0.21 \\
(0.68)\end{array}$ & $\begin{array}{l}0.29 \\
(0.44)\end{array}$ & $\begin{array}{l}0.13 \\
(0.79)\end{array}$ & $\begin{array}{l}0.38 \\
(0.31)\end{array}$ \\
\hline WATS & $\begin{array}{l}-1.06^{* * *} \\
(0.00)\end{array}$ & $\begin{array}{l}-1.06^{* * *} \\
(0.00)\end{array}$ & $\begin{array}{l}-1.21^{* * * *} \\
(0.00)\end{array}$ & $\begin{array}{l}-1.05^{* * *} \\
(0.00)\end{array}$ & $\begin{array}{l}-1.09 * * * \\
(0.00)\end{array}$ & $\begin{array}{l}-1.11^{* * *} \\
(0.00)\end{array}$ \\
\hline store_size & $\begin{array}{l}2.48 * * * \\
(0.00)\end{array}$ & $\begin{array}{l}-1.66^{* *} \\
(0.04)\end{array}$ & $\begin{array}{l}2.27^{* * *} \\
(0.01)\end{array}$ & $\begin{array}{l}-1.66^{* *} \\
(0.04)\end{array}$ & $\begin{array}{l}2.69^{* * *} \\
(0.00)\end{array}$ & $\begin{array}{l}-1.52 * \\
(0.08)\end{array}$ \\
\hline compet_ttl & & & $\begin{array}{l}0.60^{*} \\
(0.09)\end{array}$ & $\begin{array}{l}0.01 \\
(0.99)\end{array}$ & & \\
\hline compet_share & & & & & $\begin{array}{l}0.17 \\
(0.61)\end{array}$ & $\begin{array}{l}0.28 \\
(0.13)\end{array}$ \\
\hline intercept & $\begin{array}{l}-2.39 * * \\
(0.01)\end{array}$ & $\begin{array}{l}-2.26^{* * *} \\
(0.00)\end{array}$ & $\begin{array}{l}-2.68 * * * \\
(0.00)\end{array}$ & $\begin{array}{l}-2.26^{* * *} \\
(0.00)\end{array}$ & $\begin{array}{l}-2.38^{* *} \\
(0.01)\end{array}$ & $\begin{array}{l}-2.32^{* * *} \\
(0.00)\end{array}$ \\
\hline 0 & \multicolumn{6}{|c|}{ Base outcome } \\
\hline 1 & & & & & & \\
\hline enclosed & $\begin{array}{l}-0.47 \\
(0.30)\end{array}$ & $\begin{array}{l}-0.88 * \\
(0.07)\end{array}$ & $\begin{array}{l}-0.57 \\
(0.21)\end{array}$ & $\begin{array}{l}-1.12^{* *} \\
(0.02)\end{array}$ & $\begin{array}{l}-0.58 \\
(0.21)\end{array}$ & $\begin{array}{l}-1.06^{* *} \\
(0.03)\end{array}$ \\
\hline WATS & $\begin{array}{l}0.26 \\
(0.28)\end{array}$ & $\begin{array}{l}0.56^{* *} \\
(0.04)\end{array}$ & $\begin{array}{l}0.24 \\
(0.32)\end{array}$ & $\begin{array}{l}0.63 * * \\
(0.03)\end{array}$ & $\begin{array}{l}0.29 \\
(0.22)\end{array}$ & $\begin{array}{l}0.62 * * \\
(0.02)\end{array}$ \\
\hline store_size & $\begin{array}{l}-2.38 \\
(0.12)\end{array}$ & $\begin{array}{l}1.33 \\
(0.38)\end{array}$ & $\begin{array}{l}-2.54 \\
(0.10)\end{array}$ & $\begin{array}{l}1.09 \\
(0.50)\end{array}$ & $\begin{array}{l}-2.45^{*} \\
(0.09)\end{array}$ & $\begin{array}{l}1.03 \\
(0.46)\end{array}$ \\
\hline compet_ttl & & & $\begin{array}{l}0.19 \\
(0.46)\end{array}$ & $\begin{array}{l}0.46 \\
(0.14)\end{array}$ & & \\
\hline compet_share & & & & & $\begin{array}{l}-0.38 \\
(0.19)\end{array}$ & $\begin{array}{l}-0.52 * \\
(0.06)\end{array}$ \\
\hline intercept & $\begin{array}{l}-2.88 * * * \\
(0.01)\end{array}$ & $\begin{array}{l}-1.25 \\
(0.18)\end{array}$ & $\begin{array}{l}-2.94 * * * \\
(0.00)\end{array}$ & $\begin{array}{l}-1.41 \\
(0.13)\end{array}$ & $\begin{array}{l}-2.80 * * * \\
(0.01)\end{array}$ & $\begin{array}{l}-1.25 \\
(0.16)\end{array}$ \\
\hline Prob>chi2 & $0.00 * * *$ & $0.00 * * *$ & $0.00^{* * *}$ & $0.00 * * *$ & $0.00 * * *$ & $0.00 * * *$ \\
\hline Pseudo R2 & 0.1470 & 0.1190 & 0.1566 & 0.1226 & 0.1539 & 0.1301 \\
\hline Obs & 318 & 318 & 318 & 318 & 318 & 318 \\
\hline
\end{tabular}


Table 6 (continued): Multinomial logistic by size category

\begin{tabular}{|c|c|c|c|c|c|c|}
\hline \multicolumn{7}{|c|}{ Panel B - Small shopping centers } \\
\hline & \multicolumn{2}{|c|}{$(1)$} & \multicolumn{2}{|c|}{$(2)$} & \multicolumn{2}{|c|}{ (3) } \\
\hline & gla_reno & store_reno & gla_reno & store_reno & gla_reno & store_reno \\
\hline-1 & & & & & & \\
\hline enclosed & $\begin{array}{l}-1.45 \\
(0.15)\end{array}$ & $\begin{array}{l}0.67 \\
(0.20)\end{array}$ & $\begin{array}{l}-1.83 * \\
(0.08)\end{array}$ & $\begin{array}{l}0.48 \\
(0.41)\end{array}$ & $\begin{array}{l}-1.48 \\
(0.13)\end{array}$ & $\begin{array}{l}0.69 \\
(0.19)\end{array}$ \\
\hline WATS & $\begin{array}{l}0.12 \\
(0.87)\end{array}$ & $\begin{array}{l}-0.21 \\
(0.60)\end{array}$ & $\begin{array}{l}-0.2 \\
(0.84)\end{array}$ & $\begin{array}{l}-0.58 \\
(0.25)\end{array}$ & $\begin{array}{l}0.06 \\
(0.94)\end{array}$ & $\begin{array}{l}-0.2 \\
(0.62)\end{array}$ \\
\hline store_size & $\begin{array}{l}-0.06 \\
(0.84)\end{array}$ & $\begin{array}{l}-0.27 \\
(0.35)\end{array}$ & $\begin{array}{l}-0.27 \\
(0.46)\end{array}$ & $\begin{array}{l}-0.33 \\
(0.27)\end{array}$ & $\begin{array}{l}-0.05 \\
(0.86)\end{array}$ & $\begin{array}{l}-0.31 \\
(0.33)\end{array}$ \\
\hline compet_ttl & & & $\begin{array}{l}1.65^{*} \\
(0.06)\end{array}$ & $\begin{array}{l}1.18^{* *} \\
(0.05)\end{array}$ & & \\
\hline compet_share & & & & & $\begin{array}{l}-0.43 \\
(0.26)\end{array}$ & $\begin{array}{l}0.11 \\
(0.46)\end{array}$ \\
\hline intercept & $\begin{array}{l}-2.40 * * * \\
(0.01)\end{array}$ & $\begin{array}{l}-2.84 * * * \\
(0.00)\end{array}$ & $\begin{array}{l}-1.11 \\
(0.32)\end{array}$ & $\begin{array}{l}-2.09 * * \\
(0.02)\end{array}$ & $\begin{array}{l}-2.39 * * * \\
(0.00)\end{array}$ & $\begin{array}{l}-2.93 * * * \\
(0.00)\end{array}$ \\
\hline 0 & \multicolumn{6}{|c|}{ Base outcome } \\
\hline 1 & & & & & & \\
\hline enclosed & $\begin{array}{l}-0.32 \\
(0.68)\end{array}$ & $\begin{array}{l}-0.1 \\
(0.91)\end{array}$ & $\begin{array}{l}-0.82 \\
(0.41)\end{array}$ & $\begin{array}{l}-0.14 \\
(0.88)\end{array}$ & $\begin{array}{l}-0.34 \\
(0.68)\end{array}$ & $\begin{array}{l}-0.13 \\
(0.88)\end{array}$ \\
\hline WATS & $\begin{array}{l}1.17 * * \\
(0.01)\end{array}$ & $\begin{array}{l}0.62 \\
(0.16)\end{array}$ & $\begin{array}{l}1.03 * * \\
(0.02)\end{array}$ & $\begin{array}{l}0.47 \\
(0.35)\end{array}$ & $\begin{array}{l}1.14^{* *} \\
(0.02)\end{array}$ & $\begin{array}{l}0.64 \\
(0.17)\end{array}$ \\
\hline store_size & $\begin{array}{l}-0.03 \\
(0.92)\end{array}$ & $\begin{array}{l}0.36 * * * \\
(0.00)\end{array}$ & $\begin{array}{l}-0.28 \\
(0.34)\end{array}$ & $\begin{array}{l}0.29 * * \\
(0.04)\end{array}$ & $\begin{array}{l}-0.03 \\
(0.92)\end{array}$ & $\begin{array}{l}0.36 * * * \\
(0.00)\end{array}$ \\
\hline compet_ttl & & & $\begin{array}{l}1.67^{*} \\
(0.08)\end{array}$ & $\begin{array}{l}0.67 \\
(0.31)\end{array}$ & & \\
\hline compet_share & & & & & $\begin{array}{l}-0.12 \\
(0.52)\end{array}$ & $\begin{array}{l}0.08 \\
(0.66)\end{array}$ \\
\hline intercept & $\begin{array}{l}-1.43^{*} \\
(0.07)\end{array}$ & $\begin{array}{l}-2.86 * * * \\
(0.01)\end{array}$ & $\begin{array}{l}0.26 \\
(0.83)\end{array}$ & $\begin{array}{l}-2.21 * \\
(0.06)\end{array}$ & $\begin{array}{l}-1.40^{*} \\
(0.09)\end{array}$ & $\begin{array}{l}-2.90 * * * \\
(0.01)\end{array}$ \\
\hline Prob>chi2 & $0.00 * * *$ & $0.00 * * *$ & $0.00 * * *$ & $0.00 * * *$ & $0.00 * * *$ & $0.0^{* * *}$ \\
\hline Pseudo R2 & 0.1873 & 0.1268 & 0.2123 & 0.1384 & 0.1927 & 0.1284 \\
\hline Obs & 281 & 281 & 281 & 281 & 281 & 281 \\
\hline
\end{tabular}


Table 7: Logistic regression - full sample

Logistic regressions are based on a pooled sample of 1995-2000 and 2000-2005. See Table 1 for variable definitions. Continuous variables are normalized with zero mean and unit standard deviation. gla_exp equals 1 if GLA increased by $10 \%$ or more during the observation period and 0 otherwise. gla_con equals 1 if GLA decreased by $10 \%$ or more during the observation period and 0 otherwise. store_exp equals 1 if number of stores increased by $10 \%$ or more during the observation period and 0 otherwise. store_con equals 1 if number of stores decreased by $10 \%$ or more during the observation period and 0 otherwise. Total effect of large shopping centers equals the sum of all standardized coefficients associated with large shopping centers multiplied by the median value of the non-standardized variable. Net effect tests whether the sum of a standardized coefficient and its large-shopping center dummy equals zero. $p$-value is reported below coefficient estimates, $\quad p$-value is reported below coefficient estimates. Robust variance estimator is used to adjust data clustering. Fixed effect in MSA level is used. MSA dummy coefficients are not reported in the table. $p$-values are reported in parentheses. * Significant at $10 \%$; ** Significant at 5\%; *** Significant at $1 \%$.

\begin{tabular}{|c|c|c|c|c|c|c|c|c|c|c|c|c|}
\hline & \multicolumn{4}{|c|}{ (1) } & \multicolumn{4}{|c|}{ (2) } & \multicolumn{4}{|c|}{ (3) } \\
\hline & gla_exp & gla_con & store_exp & store_con & gla_exp & gla_con & store_exp & store_con & gla_exp & gla_con & store_exp & store_con \\
\hline enclosed & $\begin{array}{l}-0.26 \\
(0.47)\end{array}$ & $\begin{array}{l}-0.14 \\
(0.69)\end{array}$ & $\begin{array}{l}-0.56 \\
(0.18)\end{array}$ & $\begin{array}{l}0.37 \\
(0.22)\end{array}$ & $\begin{array}{l}-0.37 \\
(0.33)\end{array}$ & $\begin{array}{l}-0.32 \\
(0.37)\end{array}$ & $\begin{array}{l}-0.66 \\
(0.12)\end{array}$ & $\begin{array}{l}0.35 \\
(0.27)\end{array}$ & $\begin{array}{l}-0.35 \\
(0.36)\end{array}$ & $\begin{array}{l}-0.11 \\
(0.75)\end{array}$ & $\begin{array}{l}-0.67 \\
(0.12)\end{array}$ & $\begin{array}{l}0.44 \\
(0.15)\end{array}$ \\
\hline type_large & $\begin{array}{l}-1.07 \\
(0.17)\end{array}$ & $\begin{array}{l}2.55 * * * \\
(0.00)\end{array}$ & $\begin{array}{l}0.13 \\
(0.85)\end{array}$ & $\begin{array}{l}1.28 * * * \\
(0.01)\end{array}$ & $\begin{array}{l}-1.68 * * \\
(0.04)\end{array}$ & $\begin{array}{l}1.56 * * \\
(0.04)\end{array}$ & $\begin{array}{l}-0.5 \\
(0.56)\end{array}$ & $\begin{array}{l}0.7 \\
(0.24)\end{array}$ & $\begin{array}{l}-1.07 \\
(0.14)\end{array}$ & $\begin{array}{l}2.66 * * * \\
(0.00)\end{array}$ & $\begin{array}{l}0.04 \\
(0.96)\end{array}$ & $\begin{array}{l}1.39 * * * \\
(0.01)\end{array}$ \\
\hline WATS & $\begin{array}{l}1.33^{* * * *} \\
(0.00)\end{array}$ & $\begin{array}{l}-0.2 \\
(0.68)\end{array}$ & $\begin{array}{l}0.39 \\
(0.20)\end{array}$ & $\begin{array}{l}-0.24 \\
(0.56)\end{array}$ & $\begin{array}{l}1.30 * * * \\
(0.00)\end{array}$ & $\begin{array}{l}-0.38 \\
(0.46)\end{array}$ & $\begin{array}{l}0.3 \\
(0.39)\end{array}$ & $\begin{array}{l}-0.56 \\
(0.22)\end{array}$ & $\begin{array}{l}1.32 * * * \\
(0.00)\end{array}$ & $\begin{array}{l}-0.22 \\
(0.64)\end{array}$ & $\begin{array}{l}0.4 \\
(0.19)\end{array}$ & $\begin{array}{l}-0.25 \\
(0.55)\end{array}$ \\
\hline WATS*large & $\begin{array}{l}-0.93^{* *} \\
(0.03)\end{array}$ & $\begin{array}{l}-0.81 \\
(0.13)\end{array}$ & $\begin{array}{l}0.26 \\
(0.44)\end{array}$ & $\begin{array}{l}-0.75^{*} \\
(0.08)\end{array}$ & $\begin{array}{l}-0.90^{* *} \\
(0.03)\end{array}$ & $\begin{array}{l}-0.78 \\
(0.17)\end{array}$ & $\begin{array}{l}0.33 \\
(0.39)\end{array}$ & $\begin{array}{l}-0.46 \\
(0.32)\end{array}$ & $\begin{array}{l}-0.91^{* *} \\
(0.03)\end{array}$ & $\begin{array}{l}-0.79 \\
(0.13)\end{array}$ & $\begin{array}{l}0.26 \\
(0.45)\end{array}$ & $\begin{array}{l}-0.78 * \\
(0.08)\end{array}$ \\
\hline store_size & $\begin{array}{l}-0.1 \\
(0.65)\end{array}$ & $\begin{array}{l}-0.12 \\
(0.67)\end{array}$ & $\begin{array}{l}0.35^{* * * *} \\
(0.00)\end{array}$ & $\begin{array}{l}-0.33 \\
(0.26)\end{array}$ & $\begin{array}{l}-0.19 \\
(0.37)\end{array}$ & $\begin{array}{l}-0.22 \\
(0.49)\end{array}$ & $\begin{array}{l}0.29 * * \\
(0.02)\end{array}$ & $\begin{array}{l}-0.41 \\
(0.17)\end{array}$ & $\begin{array}{l}-0.11 \\
(0.65)\end{array}$ & $\begin{array}{l}-0.1 \\
(0.71)\end{array}$ & $\begin{array}{l}0.34 * * * \\
(0.00)\end{array}$ & $\begin{array}{l}-0.39 \\
(0.25)\end{array}$ \\
\hline store_size*large & $\begin{array}{l}-3.17^{* *} \\
(0.03)\end{array}$ & $\begin{array}{l}2.79 * * * \\
(0.00)\end{array}$ & $\begin{array}{l}0.36 \\
(0.80)\end{array}$ & $\begin{array}{l}-1.25 \\
(0.15)\end{array}$ & $\begin{array}{l}-3.26^{* *} \\
(0.03)\end{array}$ & $\begin{array}{l}2.73^{* * *} \\
(0.00)\end{array}$ & $\begin{array}{l}0.16 \\
(0.91)\end{array}$ & $\begin{array}{l}-1.11 \\
(0.19)\end{array}$ & $\begin{array}{l}-3.19 * * \\
(0.02)\end{array}$ & $\begin{array}{l}2.93 * * * \\
(0.00)\end{array}$ & $\begin{array}{l}0.11 \\
(0.94)\end{array}$ & $\begin{array}{l}-1.02 \\
(0.26)\end{array}$ \\
\hline $\begin{array}{l}\text { compet_ttl } \\
\text { compet_ttl*large }\end{array}$ & & & & & $\begin{array}{l}0.66 \\
(0.19) \\
-0.46 \\
(0.37)\end{array}$ & $\begin{array}{l}1.04^{*} \\
(0.08) \\
-0.53 \\
(0.44)\end{array}$ & $\begin{array}{l}0.55 \\
(0.38) \\
-0.22 \\
(0.74)\end{array}$ & $\begin{array}{l}1.08^{* *} \\
(0.05) \\
-1.08^{*} \\
(0.05)\end{array}$ & & & & \\
\hline $\begin{array}{l}\text { compet_share } \\
\text { compet_share*large }\end{array}$ & & & & & & & & & $\begin{array}{l}-0.02 \\
(0.92) \\
-0.38 \\
(0.27)\end{array}$ & $\begin{array}{l}-0.32 \\
(0.27) \\
0.5 \\
(0.24)\end{array}$ & $\begin{array}{l}0.06 \\
(0.74) \\
-0.57 * \\
(0.08)\end{array}$ & $\begin{array}{l}0.15 \\
(0.28) \\
0.15 \\
(0.47)\end{array}$ \\
\hline intercept & $\begin{array}{l}-2.11^{* * *} \\
(0.00)\end{array}$ & $\begin{array}{l}-3.91 * * * \\
(0.00)\end{array}$ & $\begin{array}{l}-2.41 * * * \\
(0.00)\end{array}$ & $\begin{array}{l}-3.46^{* * *} \\
(0.00)\end{array}$ & $\begin{array}{l}-1.51^{* *} \\
(0.04)\end{array}$ & $\begin{array}{l}-3.13^{* * *} \\
(0.00)\end{array}$ & $\begin{array}{l}-1.90^{* *} \\
(0.01)\end{array}$ & $\begin{array}{l}-2.82^{* * *} \\
(0.00)\end{array}$ & $\begin{array}{l}-2.04 * * * \\
(0.00)\end{array}$ & $\begin{array}{l}-3.96 * * * \\
(0.00)\end{array}$ & $\begin{array}{l}-2.36^{* * *} \\
(0.00)\end{array}$ & $\begin{array}{l}-3.61 * * * \\
(0.00)\end{array}$ \\
\hline Net effect & & & & & & & & & & & & \\
\hline WATS & $\begin{array}{l}0.4^{* *} \\
(0.04)\end{array}$ & $\begin{array}{l}-1.01^{* * *} \\
(0.00)\end{array}$ & $\begin{array}{l}0.65 * * * \\
(0.00)\end{array}$ & $\begin{array}{l}-0.99 * * * \\
(0.00)\end{array}$ & $\begin{array}{l}0.4^{*} \\
(0.05)\end{array}$ & $\begin{array}{l}-1.16^{* * *} \\
(0.00)\end{array}$ & $\begin{array}{l}0.63^{* *} \\
(0.01)\end{array}$ & $\begin{array}{l}-1.02^{* * *} \\
(0.00)\end{array}$ & $\begin{array}{l}0.41^{* *} \\
(0.03)\end{array}$ & $\begin{array}{l}-1.01 * * * \\
(0.00)\end{array}$ & $\begin{array}{l}0.66 * * * \\
(0.00)\end{array}$ & $\begin{array}{l}-1.03 * * * \\
(0.00)\end{array}$ \\
\hline store_size & $\begin{array}{l}-3.27 * * \\
(0.02)\end{array}$ & $\begin{array}{l}2.67 * * * \\
(0.00)\end{array}$ & $\begin{array}{l}0.71 \\
(0.62)\end{array}$ & $\begin{array}{l}-1.58^{* *} \\
(0.04)\end{array}$ & $\begin{array}{l}-3.45^{* *} \\
(0.02)\end{array}$ & $\begin{array}{l}2.51 * * * \\
(0.00)\end{array}$ & $\begin{array}{l}0.45 \\
(0.76)\end{array}$ & $\begin{array}{l}-1.52 \\
(0.05)\end{array}$ & $\begin{array}{l}-3.3 * * \\
(0.01)\end{array}$ & $\begin{array}{l}2.83 * * * \\
(0.00)\end{array}$ & $\begin{array}{l}0.45 \\
(0.73)\end{array}$ & $\begin{array}{l}-1.41 \\
(0.09 *)\end{array}$ \\
\hline compet_ttl & & & & & $\begin{array}{l}0.2 \\
(0.44)\end{array}$ & $\begin{array}{l}0.51 \\
(0.11)\end{array}$ & $\begin{array}{l}0.33 \\
(0.21)\end{array}$ & $\begin{array}{l}0.01 \\
(0.98)\end{array}$ & & & & \\
\hline compet_share & & & & & & & & & $\begin{array}{l}-0.4 \\
(0.18)\end{array}$ & $\begin{array}{l}0.18 \\
(0.56)\end{array}$ & $\begin{array}{l}-0.51^{*} \\
(0.06)\end{array}$ & $\begin{array}{l}0.3^{*} \\
(0.08)\end{array}$ \\
\hline Prob>chi2 & $0.00^{* * *}$ & $0.00 * * *$ & $0.00 * * *$ & $0.00 * * *$ & $0.00 * * *$ & $0.00 * * *$ & $0.00 * * *$ & $0.00 * * *$ & $0.00 * * *$ & $0.00 * * *$ & $0.00 * * *$ & $0.00 * * *$ \\
\hline Pseudo R2 & 0.1250 & 0.1460 & 0.0829 & 0.1444 & 0.1290 & 0.1599 & 0.0891* & 0.1497 & 0.1322 & 0.1498 & 0.0919 & 0.1508 \\
\hline Obs & 599 & 599 & 599 & 599 & 599 & 599 & 599 & 599 & 599 & 599 & 599 & 599 \\
\hline
\end{tabular}


Table 8: Logistic regression by size category

Logistic regressions are based on a pooled sample of 1995-2000 and 2000-2005. See Table 1 for variable definitions. Continuous variables are normalized with zero mean and unit standard deviation. $p$-value is reported below coefficient estimates. Robust variance estimator is used to adjust data clustering. Fixed effect in MSA level is used. MSA dummy coefficients are not reported in the table. $p$-values are reported in parentheses. * Significant at $10 \%$; ** Significant at $5 \%$; *** Significant at $1 \%$.

\begin{tabular}{|c|c|c|c|c|c|c|c|c|c|c|c|c|}
\hline \multicolumn{13}{|c|}{ Panel A Large shopping centers } \\
\hline & \multicolumn{4}{|c|}{ (1) } & \multicolumn{4}{|c|}{ (2) } & \multicolumn{4}{|c|}{ (3) } \\
\hline & gla_exp & gla_con & store_exp & store_con & gla_exp & gla_con & store_exp & store_con & gla_exp & gla_con & store_exp & store_con \\
\hline enclosed & $\begin{array}{l}-0.45 \\
(0.30)\end{array}$ & $\begin{array}{l}0.14 \\
(0.76)\end{array}$ & $\begin{array}{l}-0.91^{*} \\
(0.07)\end{array}$ & $\begin{array}{l}0.38 \\
(0.30)\end{array}$ & $\begin{array}{l}-0.51 \\
(0.25)\end{array}$ & $\begin{array}{l}-0.12 \\
(0.81)\end{array}$ & $\begin{array}{l}-1.16^{* *} \\
(0.02)\end{array}$ & $\begin{array}{l}0.39 \\
(0.30)\end{array}$ & $\begin{array}{l}-0.57 \\
(0.21)\end{array}$ & $\begin{array}{l}0.21 \\
(0.65)\end{array}$ & $\begin{array}{l}-1.10^{* *} \\
(0.03)\end{array}$ & $\begin{array}{l}0.47 \\
(0.20)\end{array}$ \\
\hline WATS & $\begin{array}{l}0.41^{*} \\
(0.06)\end{array}$ & $\begin{array}{l}-1.10 * * * \\
(0.00)\end{array}$ & $\begin{array}{l}0.75^{* * * *} \\
(0.00)\end{array}$ & $\begin{array}{l}-1.11^{* * *} \\
(0.00)\end{array}$ & $\begin{array}{l}0.42^{*} \\
(0.05)\end{array}$ & $\begin{array}{l}-1.25 * * * \\
(0.00)\end{array}$ & $\begin{array}{l}0.82 * * * \\
(0.00)\end{array}$ & $\begin{array}{l}-1.10^{* * *} \\
(0.00)\end{array}$ & $\begin{array}{l}0.44 * * \\
(0.04)\end{array}$ & $\begin{array}{l}-1.14 * * * \\
(0.00)\end{array}$ & $\begin{array}{l}0.81^{* * * *} \\
(0.00)\end{array}$ & $\begin{array}{l}-1.16^{* * *} \\
(0.00)\end{array}$ \\
\hline $\begin{array}{l}\text { store_size } \\
\text { compet_ttl }\end{array}$ & $\begin{array}{l}-2.80^{*} \\
(0.06)\end{array}$ & $\begin{array}{l}2.80 * * * \\
(0.00)\end{array}$ & $\begin{array}{l}1.65 \\
(0.28)\end{array}$ & $\begin{array}{l}-1.78^{* *} \\
(0.03)\end{array}$ & $\begin{array}{l}-2.92 * \\
(0.05) \\
0.14 \\
(0.60)\end{array}$ & $\begin{array}{l}2.62 * * * \\
(0.00) \\
0.58 \\
(0.11)\end{array}$ & $\begin{array}{l}1.39 \\
(0.39) \\
0.5 \\
(0.12)\end{array}$ & $\begin{array}{l}-1.76^{* *} \\
(0.03) \\
-0.04 \\
(0.87)\end{array}$ & $\begin{array}{l}-2.88 * * \\
(0.04)\end{array}$ & $\begin{array}{l}3.03^{* * *} \\
(0.00)\end{array}$ & $\begin{array}{l}1.31 \\
(0.35)\end{array}$ & $\begin{array}{l}-1.62 * \\
(0.07)\end{array}$ \\
\hline compet_share & & & & & & & & & $\begin{array}{l}-0.4 \\
(0.17)\end{array}$ & $\begin{array}{l}0.22 \\
(0.51)\end{array}$ & $\begin{array}{l}-0.58^{* *} \\
(0.03)\end{array}$ & $\begin{array}{l}0.32 * \\
(0.08)\end{array}$ \\
\hline Intercept & $\begin{array}{l}-3.18^{* * *} \\
(0.00)\end{array}$ & $\begin{array}{l}-2.42^{* * *} \\
(0.01)\end{array}$ & $\begin{array}{l}-1.41 \\
(0.14) \\
\end{array}$ & $\begin{array}{l}-2.46^{* * *} \\
(0.00)\end{array}$ & $\begin{array}{l}-3.23 * * * \\
(0.00)\end{array}$ & $\begin{array}{l}-2.70^{* * *} \\
(0.00)\end{array}$ & $\begin{array}{l}-1.57^{*} \\
(0.10)\end{array}$ & $\begin{array}{l}-2.45^{* * *} \\
(0.00)\end{array}$ & $\begin{array}{l}-3.09 * * * \\
(0.00)\end{array}$ & $\begin{array}{l}-2.42 * * * \\
(0.01)\end{array}$ & $\begin{array}{l}-1.39 \\
(0.12) \\
\end{array}$ & $\begin{array}{l}-2.53^{* * *} \\
(0.00)\end{array}$ \\
\hline Prob>chi2 & $0.08^{*}$ & $0.00 * * *$ & $0.09 *$ & $0.00 * * *$ & $0.04 * *$ & $0.00 * * *$ & $0.09 *$ & $0.00 * * *$ & $0.03 * *$ & $0.00 * * *$ & $0.00^{* * *}$ & $0.00 * * *$ \\
\hline Pseudo R2 & 0.1051 & 0.1702 & 0.0905 & 0.1167 & 0.1062 & 0.1868 & 0.1024 & 0.1168 & 0.1161 & 0.1735 & 0.1102 & 0.1257 \\
\hline Obs & 318 & 304 & 318 & 301 & 318 & 304 & 318 & 301 & 318 & 304 & 318 & 301 \\
\hline \multicolumn{13}{|c|}{ Panel B Small shopping centers } \\
\hline & \multicolumn{4}{|c|}{ (1) } & \multicolumn{4}{|c|}{$(2)$} & \multicolumn{4}{|c|}{ (3) } \\
\hline & gla_exp & gla_con & store_exp & store_con & gla_exp & gla_con & store_exp & store_con & gla_exp & gla_con & store_exp & store_con \\
\hline Enclosed & $\begin{array}{l}-0.21 \\
(0.79)\end{array}$ & $\begin{array}{l}-1.38 \\
(0.17)\end{array}$ & $\begin{array}{l}-0.23 \\
(0.79)\end{array}$ & $\begin{array}{l}0.69 \\
(0.19)\end{array}$ & $\begin{array}{l}-0.64 \\
(0.51)\end{array}$ & $\begin{array}{l}-1.69^{*} \\
(0.10)\end{array}$ & $\begin{array}{l}-0.26 \\
(0.77)\end{array}$ & $\begin{array}{l}0.51 \\
(0.37)\end{array}$ & $\begin{array}{l}-0.21 \\
(0.79)\end{array}$ & $\begin{array}{l}-1.39 \\
(0.15)\end{array}$ & $\begin{array}{l}-0.27 \\
(0.75)\end{array}$ & $\begin{array}{l}0.71 \\
(0.17)\end{array}$ \\
\hline WATS & $\begin{array}{l}1.16^{* *} \\
(0.01)\end{array}$ & $\begin{array}{l}-0.05 \\
(0.95)\end{array}$ & $\begin{array}{l}0.63 \\
(0.15)\end{array}$ & $\begin{array}{l}-0.26 \\
(0.52)\end{array}$ & $\begin{array}{l}1.03^{* *} \\
(0.02)\end{array}$ & $\begin{array}{l}-0.33 \\
(0.73)\end{array}$ & $\begin{array}{l}0.5 \\
(0.31)\end{array}$ & $\begin{array}{l}-0.62 \\
(0.22)\end{array}$ & $\begin{array}{l}1.12 * * \\
(0.02)\end{array}$ & $\begin{array}{l}-0.13 \\
(0.84)\end{array}$ & $\begin{array}{l}0.65 \\
(0.16)\end{array}$ & $\begin{array}{l}-0.25 \\
(0.54)\end{array}$ \\
\hline $\begin{array}{l}\text { store_size } \\
\text { compet_ttl }\end{array}$ & $\begin{array}{l}-0.02 \\
(0.93)\end{array}$ & $\begin{array}{l}-0.04 \\
(0.89)\end{array}$ & $\begin{array}{l}0.37 * * * \\
(0.00)\end{array}$ & $\begin{array}{l}-0.31 \\
(0.27)\end{array}$ & $\begin{array}{l}-0.25 \\
(0.39) \\
1.54^{*} \\
(0.10)\end{array}$ & $\begin{array}{l}-0.24 \\
(0.54) \\
1.54^{*} \\
(0.08)\end{array}$ & $\begin{array}{l}0.32 * * \\
(0.02) \\
0.56 \\
(0.39)\end{array}$ & $\begin{array}{l}-0.38 \\
(0.19) \\
1.10^{*} \\
(0.06)\end{array}$ & $\begin{array}{l}-0.02 \\
(0.94)\end{array}$ & $\begin{array}{l}-0.03 \\
(0.92)\end{array}$ & $\begin{array}{l}0.37 * * * \\
(0.00)\end{array}$ & $\begin{array}{l}-0.35 \\
(0.26)\end{array}$ \\
\hline compet_share & & & & & & & & & $\begin{array}{l}-0.11 \\
(0.55)\end{array}$ & $\begin{array}{l}-0.41 \\
(0.29)\end{array}$ & $\begin{array}{l}0.07 \\
(0.68)\end{array}$ & $\begin{array}{l}0.11 \\
(0.48)\end{array}$ \\
\hline intercept & $\begin{array}{l}-1.52^{*} \\
(0.05)\end{array}$ & $\begin{array}{l}-2.69 * * * \\
(0.00)\end{array}$ & $\begin{array}{l}-2.92 * * * \\
(0.01)\end{array}$ & $\begin{array}{l}-2.93^{* * *} \\
(0.00)\end{array}$ & $\begin{array}{l}0.07 \\
(0.96)\end{array}$ & $\begin{array}{l}-1.45 \\
(0.20)\end{array}$ & $\begin{array}{l}-2.37^{* *} \\
(0.04)\end{array}$ & $\begin{array}{l}-2.26 * * \\
(0.01)\end{array}$ & $\begin{array}{l}-1.51^{*} \\
(0.06)\end{array}$ & $\begin{array}{l}-2.72^{* * *} \\
(0.00)\end{array}$ & $\begin{array}{l}-2.96 * * * \\
(0.01)\end{array}$ & $\begin{array}{l}-3.01^{* * *} \\
(0.00)\end{array}$ \\
\hline Prob>chi2 & $0.02^{* *}$ & 0.77 & $0.02^{* *}$ & 0.19 & $0.00^{* * *}$ & 0.77 & $0.03^{* *}$ & $0.08^{*}$ & $0.01 * *$ & 0.64 & $0.03^{* *}$ & 0.29 \\
\hline Pseudo R2 & 0.1702 & 0.0763 & 0.1324 & 0.0750 & 0.1951 & 0.1016 & 0.1376 & 0.0902 & 0.1717 & 0.0851 & 0.1333 & 0.0772 \\
\hline Obs & 216 & 216 & 254 & 258 & 216 & 216 & 254 & 258 & 216 & 216 & 254 & 258 \\
\hline
\end{tabular}

